IV. Studies of the Blattidae. By R. Shelford, M.A., F.L.S.

[Read February 3rd, 1909.]

\title{
Plates VII-IX.
}

\section{A revision of the Old-World Blattinae belong- ING TO THE POLYZOSTERIA GROUP.}

A STUDY of the collection of Blattidae recently made in West Australia by Drs. Michaelsen and Hartmeyer soon convinced me that a thorough revision of the Australian Blattinae was an urgent necessity. Tepper has described numbers of species in the Transactions of the Royal Society of South Australia, but the identification of his species has always been attended with considerable difficulty since this worker's views on classification are rather peculiar and his descriptions are not supplemented with figures. Kirby, in his Synonymic Catalogue of Orthoptera vol. $i$, has made a laudable endeavour to reduce the Tepperian species and genera into something like order, but as he had neither time nor opportunity to consult any types but those of Walker, he has not succeeded in decreasing the confusion. Guessing at the generic identity of species involves all sorts of risks, and consequently $\mathrm{Mr}$. Kirby's emendation of Tepper's genera has resulted in several serious errors. To take one example:- he sinks Temnelytra, Tepp., as a synonym of Zonioploca, Stål, though the two genera are totally distinct, and includes in the revised genus species belonging to no less than five genera. The straightening-out of the terrible tangle into which this group of cockroaches had been twisted has been attended with very great difficulty, for I have been unable to borrow types from the South Australian Museum and Mr. Tepper has not responded to appeals for the comparison with his types of specimens sent to him from the Hope collection. Fortunately Professor Baldwin Spencer and Mr. W. W. Froggatt most kindly came to the rescue; the former has sent me all the Tepperian types in the Melbourne Museum, and the latter has presented or lent to the Hope Museum specimens determined by Mr. Tepper himself. With these valuable aids, for which I cannot be too grateful, I have been able to determine

TRANS. ENT. SOC. LOND. 1909.-PART II. (MAY) 
with accuracy the great majority of genera and species described by Mr. Tepper; in addition the types of Walker in the British Museum have been examined. Dr. Th. Kuhlgatz, late of the Berlin Museum, has sent me drawings of Erichson's types and has compared specimens sent to him. Dr. K. Holdhaus of Vienna has lent me some of Brunner's types and Dr. Y. Sjöstedt of Stockholm all the types of Stål. I trust that the net result of the considerable correspondence and hard work expended on this memoir is a satisfactory classification which will bear the test of time and enable other workers to identify the species of the group without great difficulty.

The Blattinae can be divided into two chief sections according to the structure of the posterior tarsi ; the first section, which may be styled the Polyzosteria-group, has the posterior metatarsus usually shorter than the succeeding joints and usually unarmed beneath, ${ }^{*}$ the succeeding joints are entirely unarmed and with large pulvilli; the second section or Blatta-group has the posterior metatarsus longer than the succeeding joints and armed beneath, the second and third joints are also armed and their pulvilli are apical (Pl. III, f. 40). A revision of the second section I hope to undertake on some future occasion. The Polyzosteria-group can be subdivided into an Old-World group and a New-World group, but the character on which this subdivision is based-the relative distances apart of the eyes and the antennal sockets-is so subtle that I doubt its practical importance and I temporarily regard the New-World group as distinct from the OldWorld group for convenience sake only. In the Old World, Australia is undoubtedly the head-quarters of the Polyzosteria-group, nearly all the apterous species are confined to that continent and the islands immediately surrounding it; but one or two, and notably Cutilia nitida, Br., have a much wider range, extending into the Oriental region and Polynesian islands. The occurrence of an allied species at Bombay is very singular and an error in locality is suggested. As might be expected the winged species (genus Methana) have a wider range than is characteristic of the wingless forms, but even these do not extend to the Asiatic mainland. The group in Africa is represented by the single monotypic genus Paramethana. The geographical distribution of these cockroaches would appear to

$$
\text { * Cutilia is an exception. }
$$


favour the view that they constitute a somewhat primitive group, for Australia is universally regarded as the last refuge of animal forms that have disappeared from the less isolated quarters of the globe. But I do not think that the Blattinae as a whole can be considered as other than the most highly evolved group of cockroaches, since the structure of the genital valves in the female sex is certainly a peculiar modification and not a primitive character, whilst the male genitalia are more complex than in many other subfamilies. Whether the Blattagroup is more primitive than the Polyzosteria-group, is open to argument, but I am inclined to think that it is not.

Structurally the Polyzosteriae offer valuable diagnostic characters, especially in the male sex, so that the separation of the species is not attended with the difficulties that confront one when dealing with such homogeneous genera as Epilampra, Blabera, Gyna, etc.; but the allocation of the females of some genera to their respective males is not easy and the descriptions of new species from females alone ought to be avoided in future.

Bionomically these insects are very interesting: some are brightly coloured, e.g. Euzosteria mitchellii, and the shining black species of Platyzosteria must also be very conspicuous. Many of the species have a disgusting odour, and one species of Cosmozosteria identified by Mr. J. J. Walker as $C$. lateralis extrudes from the apex of the abdomen when irritated a red vesicle and emits an odour so pungent that Mr. Walker was deterred from capturing specimens. Mr. Froggatt tells me that all the species expose themselves freely and are frequently found basking on the tops of fence-posts. The egg-capsules of a few species are known, and are typically Blattine in form.

\section{KEY TO GENERA.}

1. Ocelli usually absent. Tegminal rudiments absent. Abdominal tergites with well-marked stigmatic dots. Supraanal lamina ( $q$ ) more or less bilobate. Cerci blunt and flattened, generally not extending beyond the supra-anal lamina.

2. Tibial spines in two rows . . . . Polyzosteria, Burm.

$2^{\prime}$. Tibial spines in three rows . . . . Euzosteria, nov. 
1'. Ocelli present. Tegmina present, rudimentary or absent. Abdominal tergites rarely with stigmatic dots. Supra-anal lamina ( $q$ ) not bilobate. Cerci longer, apex usually acuminate.

2. Wings absent or rudimentary. Tegmina rudimentary or absent.

3. Tegmina absent or represented by squamiform lobes.

4. Posterior angles of the 5th and 6th abdominal tergites backwardly produced.*

5. Posterior metatarsus short, not spined beneath or with only a few spines; its pulvillus usually large, and occupying at least half of the joint.

6. Lateral margins of pronotum not incrassated. Thoracic tergites more or less smooth and nitid.

7. Supra-anal lamina ( $\tilde{\sigma})$ not produced to form an acute spine . . . . . Platyzosteria, Br.

7'. Supra-anal lamina $(\hat{\delta})$ produced to form an acute spine. . . .

6'. Lateral margins of pronotum incrassated. Thoracic tergites punctate or tuberculate . . . . . .

5'. Posterior metatarsus longer, spined beneath, its pulvillus not occupying one half of the joint . . . . . . . Zonioploca, Stål.

Leptozosteria, Tepp.

$4^{\prime}$. Posterior angles of the 5th and 6 th abdominal tergites not backwardly produced, or if produced the abdominal tergites are scabrous, Tegmina entirely absent.

* Cutilia sedilloti, Bol. (ô), is an exception. 
5. Posterior angles of 7 th abdominal tergite backwardly produced; abdomen above scabrous. . . . . . Cosmozosteria, Stål.

5 . Posterior angles of 7 th abdominal tergite not backwardly produced; abdomen above smooth, nitid.

6. Lateral margins of pronotum not incrassated. . . . Anamesia, Tepp.

6'. Lateral margins of pronotum incrassated . . . . . . Desmozosteria, Shelf.

3'. Tegmina quadrate, as long as the pronotum.

4. Wings absent . . . . . . Temnelytra, Tepp.

4'. Wings rudimentary . . . . . Scabina, nov.

2 '. Tegmina and wings well developed.

3. Pronotum anteriorly parabolic, sides deflexed . . . . . . . . .

3'. Pronotum discoidal, sides not deflexed . . . . . . Paramethana, Shelf.

Genus 1. Polyzosteria, Burm.

Polyzosteria, Burmeister, Handb. Ent. ii, p. 482 (1838); Brunner von Wattenwyl, Nouv. Syst. Blatt., p. 203 (1865). Chalcolampra, Saussure, Mém. Soc. Sc. Phys. Nat., Genève, xvii, p. 132 (1863) (preoccupied in Coleoptera).

Characters. Ocelli absent. Antennae shorter than the body. Pronotum anteriorly somewhat cucullate, margins not reflected, posteriorly truncate. Tegmina and wings entirely absent. Posterior angles of the 7th abdominal tergite strongly produced backwards, angles of the preceding tergites not, or scarcely, produced, angles of the 9 th tergite sometimes lobiform (cf. fig. 1). Stigmatic dots on abdominal tergites well-marked. Supra-anal lamina, $(\delta)$ quadrate, angles acute, ( $q$ ) sub-bilobate, cucullate. Sub-genital lamina ( $\delta$ ) sub-quadrate, styles short, obtuse. Cerci short, flattened, blunt at apex. Tibiae robust, almost quadrangular in section, spines on outer aspect in 2 rows. Posterior metatarsus very short, unarmed beneath, its pulvillus occupying the greater part of the joint.

\section{KEY TO THE SPECIES.}

1. Dorsal surface margined or spotted with nchreous yellow.

TRANS. ENT. SOC. LOND. 1909.-PART II. (MAY) 
2. Legs aeneous.

3. Body above without tubercles.

4. Pronotum with 2-4 deep punctures on the disc . . . . . P. limbata, Burm.

4'. Pronotum without these punctures . . . . . . . P. iridicolor, Tepp.

3'. Body above with tubercles . . P. bagoti, Tepp.

2'. Legs testaceous or castaneous.

3. Pronotum not tuberculate.

4. Posterior margin of pronotum not ochreous-yellow . . . . .

4'. Posterior margin of pronotum ochreous-yellow . . . .

3'. Pronotum tuberculate . . . . . P.obscuroviridis, Tepp.

1'. Dorsal surface unicolorous (except for margins of supra-anal lamina and cerci).

2. Large species with dense sericeous pile. $P$. pubescens, Tepp.

2 '. Smaller species, sericeous pile absent or very sparse.

3. Dorsal surface tuberculate. . . . P. oculata, Tepp.

3'. Dorsal surface not tuberculate.

4. Colour dull bronze . . . . . P. invisa, Walk.

4'. Colour metallic green . . . P. viridissima, sp. n.

The above key must be regarded as merely provisional, for I have not been able to see all the species described by Tepper, and from the descriptions alone of these it is not possible to determine their generic position with exactitude.

1. P. limbata, Burm.

Polyzosteria limbata, Burmeister, Handb. Ent., ii, p. 483 (1838).

Polyzosteria aenea, Burmeister, t. c., p. 483 (1838).

Polyzosteria purpurascens, Fischer, Orth. Eur., p. 93 (1853).

Polyzosteria pulchella, Saussure, Rev. Zool. (2), xvi, p. 308 (1864).

Polyzosteria nitens, Walker, Cat. Blatt. Brit. Mus., p. 155 (1868).

? Polyzosteria frenchii, Tepper, Tr. R. Soc. S. Australia, xviii, p. 178 (1894).

The species is well known and does not require redescription. It is very variable, as can be guessed from 
the synonymy. A study of a long series convinces me that aenea is merely a colour variety of limbata; in typical limbata the colour is blackish and the yellow lateral margins of the pronotum are broad, whereas in typical aenea the colour is greenish-bronze and the pronotum is very narrowly flavo-marginate, but I have seen several intermediate specimens. The two examples of $P$. nitens in the British Museum look as if they had been varnished, but they show no characters whereby they can be separated from typical limbata. The only specimen of $P$. frenchii that I have seen is in the Melbourne Museum, it was determined by Mr. Tepper himself and is certainly the same as $P$. limbata. I have not seen the type.

New South Wales; Victoria; South and West Australia; Tasmania.

2. P. iridicolor, Tepp.

Polyzosteria iridicolor, Tepper, Tr. R. Soc. S. Australia, xvii, p. 73 (1893).

Known to me only by the description.

South Australia, Gawler range. (Adelaide Mus., type.)

3. P. bagoti, Tepp.

Polyzosteria bagoti, Tepper, t.c., p. 79 (1893).

Known to me only by the description. It appears to be distinguished by the dorsal surface furnished with "irregular low tubercles." As it is only $14-16.5 \mathrm{~mm}$. in length, it is probably the larva of some previously described species.

South Australia, Port Augusta. (Adelaide Mus., type.)

4. P. cuprea, Sauss.

Polyzosteria cuprea, Saussure, Mém. Soc. Sc. Phys. Nat. Genevè, xvii, p. 133, Pl. I, f. 2 (1864).

Polyzosteria maculata, Brunner von Wattenwyl, Nouv.

Syst. Blatt., p. 206 (1865).

A well-known species.

South and West Australia. 
5. P. impressa, Tepp.

Polyzosteria impressa, Tepper [in] Horn Exped. Centr. Australia, ii, p. 361 (1896).

Known to me only from the description which I reproduce herewith.

“ $q$. Metallic blackish glaucous ; fore- and hind-margin of pronotum and the hind-margins of all the other segments narrowly yellow. Face, antennae, legs (except ochreous coxae) and ventral segments of abdomen, brownish-red. Vertex of head dull metallic green, punctate; fore margin of clypeus whitish. Pronotum hooded, lateral margin broad, reflexed, impressed cribriform, rugulose, hind-angles moderately rounded; discal area limited by a semicircular interrupted impression, in front a low elevation succeeded by an inversely curved depression, and on each side of the middle an elongated pit; hind-margin concave. Meso- and meta-notum with similar sculpture and transverse impressions ; hind-angles of former distinctly produced, hind-margin straight ; of latter, hind-anglesnot produced, hind-margin very sinuous. Abdomen short, very slightly rugulose, margin of last two segments finely crenulate and hind-angles produced; 1st ventral segment and coxae bordered pale. Supra-anal, lamina very flat and short, rotundate, entire, rugulose. Cerci very short, acuminate, pale yellow.

Total length $28 \mathrm{~mm}$. ; pronotum $8 \mathrm{~mm} . \times 18 \mathrm{~mm} . "$

\section{Central Australia.}

6. P. obscuroviridis, Tepp.

Polyzosteria obscuroviridis, Tepper, Tr. R. Soc. S. Australia, xvii, p. 73 (1893).

Unknown to me; it is distinguished by the pronotum, "studded with irregular rows of large raised tubercles" and by the bicolorous legs.

South Australia, Gawler range. (Adelaide Mus., type.)

7. P. pubescens, Tepp. (Plate VII, fig. 1).

Polyzosteria pubescens, Tepper, t. c., p. 75 (1893) ; Froggatt, Australian Insects, p. 19, fig. 6 (1907).

Fuscous, with a greenish tinge, all the tergites very narrowly bordered posteriorly with testaceous. Dorsal surface with a dense 
grey sericeous pile more or less worn along the middle line. Body subtectiform. Dorsal surface scabrous. Frons concave and rugosely punctate. Antennae ochreous. Pronotum anteriorly cucullate, anterior margin sub-sinuate. Body beneath ochreous outwardly margined with castaneous, apex of the abdomen castaneous. Cerci ochreous. Supra-anal lamina, ( $\left(\begin{array}{l}) \\ )\end{array}\right)$ sub-quadrate, $(q)$ produced, cucullate, apex emarginate. 9th abdominal tergite backwardly produced at its outer angles to form two blunt processes, outwardly margined with ochreous. Coxae testaceous with a castaneous stripe, femora, tibiae and tarsi castaneous with a metallic tinge. Femora beneath and tibial spines testaceous. Femoral spines very small.

Length (of ) 30-34 mm., ( q ) 40-44 mm. ; pronotum 10-11.5 mm. $\times 20-25 \mathrm{~mm}$.

West Australia (Oxford Mus.; Hamburg Mus.; Melbourne Mus.; Adelaide Mus., type).

8. P. oculata, Tepp.

Polyrosteria (sic) oculata, Tepper, t. c., p. 75 (1893).

Dull bronze above with irregular rows of flattened tubercles. Stigmatic dots very prominent. Laterally with faint indications of a sericeous pile. Cerci and supra-anal lamina edged with ochreous. Head rugose, frons not concave. Antennae castaneous at base, remainder fuscous. Underside of thoracic tergites orange. Abdomen beneath castaneous with metallic sheen, the underside of the lateral margins of the 7th abdominal tergite brilliant metallic green. Supra-anal lamina, ( $\delta$ ) quadrate, posteriorly widely emarginate, (१) produced, broad, deeply emarginate. Sub-genital lamina (o) sub-quadrate; styles stout, incurved, their apices acuminate. Posterior angles of 7 th abdominal tergite very strongly produced backwards, angles of 9th tergite as in P. pubescens. Coxae margined with ochreous; femora castaneous, tibiae dark metallic green, spines ochreous tipped with rufous.

Length (of and q) $31 \mathrm{~mm}$. ; pronotum $9.3 \mathrm{~mm} . \times 19 \mathrm{~mm}$.

South Australia; Victoria (Oxford Mus.; Melbourne Mus., ô type ; Adelaide Mus., o type).

9. P. invisa, Walk.

Polyzosteria invisa, Walker, Cat. Blatt. Brit. Mus., p. 162 (1868).

Ovate and depressed. Dark purplish above; finely rugose-punctate, not tuberculate. Posterior margin of supra-anal lamina, 
margins of cerci, margins of coxae and apices of femora, ochreous yellow. Supra-anal lamina, $(\delta)$ with posterior angles very acute, all the margins concave, ( $q$ ) sub-bilobate, scarcely cucullate. Posterior angles of 7 th abdominal tergite less strongly produced than in the preceding species. Coxæ, femora and apex of abdomen beneath castaneous. Genital styles incurved, short, obtuse. Tibiae above shining blue, beneath piceous, spines testaceous tipped with fuscous.

Total length (ot ) $28 \mathrm{~mm}$., ( $q$ ) $20 \mathrm{~mm}$. ; pronotum 9-9.5 mm. $\times 17$ $19 \mathrm{~mm}$.

\section{“Australia" (British Mus., type; Oxford Mus.).}

The form of the supra-anal lamina of the $\hat{\sigma}$ is characteristic.

10. $P$. viridissima, sp. $\mathrm{n}$.

q. Dark aeneous-green, margins of the coxae, outer apical angles of the coxae, cerci beneath and outer margins above, extreme apices of femora beneath, testaceous. Antennae, mouth-parts and genital valves piceous. Dorsal surface finely punctate. Abdominal stigmata distinct. Supra-anal lamina cucullate, apex not emarginate, not exceeded by the cerci which are flattened, blunt and with the articulation obscure. Tibial spines castaneous.

Length $26.5 \mathrm{~mm}$; pronotum $8 \mathrm{~mm}$. $\times 15.2 \mathrm{~mm}$.

New South Wales, Mt. Kosciusko ( $W$. W. Froggatt), (British Mus., type).

The species is much more convex than $P$. invisa and the shade of the supra-anal lamina is different; it may possibly be conspecific with $P$. iridicolor, but it is certainly differently coloured.

\section{Genus 2. Euzosteria, nov.}

Polyzosteria, auctorum (partim).

Characters. Similar to Polyzosteria but the spines on outer aspect of tibiae triseriately arranged. Margins of pronotum more or less reflected. Ocelli occasionally present. Supra-anal lamina, (§) with less acute angles, ( $q$ ) more rounded, less bilobate.

Type of the genus-E. subverrucosa, White.

\section{KEY TO THE SPECIES.}

1. Margins of pronotum strongly reflexed.

2. Tibiae testaceous . . . . . $\left\{\begin{array}{l}\text { E. subvermucosa, White } \\ \text { E. subreflexa, Tepp. }\end{array}\right.$ 
Mr. R. Shelfurd's Studies of the Blattidae.

2'. Tibiae metallic blue or green . . . E. nobilis, Br.

1'. Margins of pronotum not or scarcely reflexed.

2. Lateral margins of pronotum broadly testaceous, disc aeneous . . . . E. patula, Walk.

2'. Pronotum castaneous or greenish with

4 oblique testaceous stripes . . . E. mitchellii, Angas.

1. E. subverrucosa, White.

Blatta subverrucosa, White [in] Grey, Journ. Exped. Australia, ii, p. 467 (1841).

Polyzosteria reflexa, Brunner von Wattenwyl, Nouv.

Syst. Blatt., p. 208 (1865).

Polyzosteria femoralis, Walker, Cat. Blatt. Brit. Mus., p. 156 (1868).

Polyzosteria figurata, Walker, op. cit., p. 157 (1868).

A common and well-known species; figurata is merely a larval form.

South and Western Australia.

2. E. subreflexa, Tepp.

Polyzosteria subreflexa, Tepper, Tr. R. Soc. S. Australia, xix, p. 158 (1895).

The diagnosis does not show how this species differs from the preceding.

South Australia, Ooldea (Adelaide Mus., type).

3. E. nobilis, Br.

Polyzosteria nobilis, Brunner von Wattenwyl, Nouv. Syst. Blatt., p. 209 (1865).

Polyzosteria subnobilis, Tepper, Tr. R. Soc. S. Australia, xvii, p. 81 (1893).

Tepper failed to recognise Brunner's species, his description of subnobilis corresponds exactly with nobilis; the smooth spaces that he describes on the abdominal tergites are hidden in contracted examples.

South Australia, Adelaide, Kangaroo Is.; West Australia, Swan River (Vienna Mus., type; British Mus.; Oxford Mus.; Adelaide Mus., type of subnobilis). 
4. E. patula, Walk. (Pl. VII, fig. 2.)

Polyzosteria patula, Walker, Cat. Blatt. Brit. Mus p. 157 (1868).

Broadly elliptical. Above dark aeneous-green, posterior margins of thoracic tergites narrowly testaceous interrupted by maculae of the ground colour, posterior margins of abdominal tergites with flavo-testaceous maculae. Dorsal surface finely rugose. Head aeneous, coarsely rugose; mouth-parts flavo-testaceous; antennae castaneous at base, remainder rufous. Pronotum with lateral margins slightly incrassated and elevated, lateraliy broadly testaceous, posterior angles slightly produced. Supra-anal lamina, ( $\left.\delta^{\star}\right)$ subquadrangular, lateral margins serrate, (q) rugose, trigonal, apex not emarginate. Cerci very short, not exceeding the lamina, testaceous. Posterior angles of 7th abdominal tergite scarcely produced, 8th abdominal tergites with spiracles visible at their external angles; external angles of 9th tergite produced as blunt processes. Beneath testaceous. Legs testaceous, with upper aspect of femora and tibiae brilliant metallic green.

Length (f) $30 \mathrm{~mm}$. , (f) $33 \mathrm{~mm}$. , pronotum (f) $10 \mathrm{~mm} . \times$ $20 \mathrm{~mm}$., (q) $11.5 \mathrm{~mm} . \times 22 \mathrm{~mm}$.

This is a somewhat aberrant species and appears to be intermediate between Euzosteria and Anamesia.

South Australia, Northern Territory (British Mus., type; Adelaide Mus.); Western Australia, Towranna plains (Oxford Mus.).

5. E. mitchellii, Angas.

Blatta mitchellii, Angas, S. Australia Illustr. Pl. XLVIII, fig. 1 (1847).

Polyzosteria mitchellii, Saussure, Mém. Sci. Phys. Nat. Genève, xxiii, p. 106 (1873); Tepper, Tr. R. Soc. S. Australia, xvii, p. 78 (1893); Froggatt, Australian Insects, p. 19, fig. 5 (1907).

Tepper describes the colours of fresh specimens, which are very brilliant. In the female the pronotum anteriorly is parabolic, whereas in the male it is widely arched and subsinuate, the measurements show the difference in form very clearly ( क $10 \mathrm{~mm} . \times 21 \mathrm{~mm}$., of $11 \mathrm{~mm} . \times 21 \mathrm{~mm}$.) ; this sexual dimorphism in the form of the pronotum is unusual.

Victoria; S. Australia; Western Australia. 
Genus 3. Platyzosteria, Br.

Platyzosteria, Brunner von Wattenwyl, Nouv. Syst. Blatt., p. 204 (1865).

Melanozosteria, Stål, Bih. Svensk. Akad. ii (13), p. 13, (1874).

Syntomapterc, Tepper, Tr. R. Soc. S. Australia, xvii, p. 106 (1893).

Drymaplaneta, Tepper, t. c., p. 109 (1893).

Characters. Ocelli absent. Antennae shorter than the body. Body depressed. Vertex of head not covered by pronotum. Pronotum not cucullate, its margins not reflected. Rudiments of tegmina present as squamiform lobes or absent. Wings absent. Posterior angles of all the abdominal tergites produced, those of the distal tergites strongly produced and spiniform. Supra-anal lamina variable in shape but never sub-bilobate in $q$. Genital styles long, slender, acuminate. Cerci frequently exceeding the supra-anal lamina, apex acuminate. Tibiae moderately spined, spines on outer aspect triseriately arranged. Posterior metatarsus very short, not spined beneath or with only a few spines, its pulvillus covering the greater part of the joint beneath.

Type of the genus-P. melanaria, Erichs.

Melanozosteria, Stal, is founded on a species of Platyzosteria erroneously identified as nitida, Br. Syntomaptera, Tepp., includes six species of Platyzosteria which the author quite incorrectly regards as allied to Periplaneta; Kirby for no obvious reason selects scabriuscula, Tepp., as the type of the genus (Syn. Cat. Orth., i, p. 129, 1904). Drymaplaneta, Tepp., is based on variable and larval characters and cannot possibly stand.

\section{KEY TO THE SPECIES.}

1. Uniform piceous or castaneous (cf., however, P. bicolor, Kirby).

2. Tegminal rudiments absent.

3. Dorsal surface not or only faintly scabrous.

4. Thoracic tergites not transversely seriate-punctate.

5 . Vertex of head not orange rufous. 
6. Supra-anal lamina, (ఫึ) sub-quadrate or trigonal, apex emarginate, ( $q$ ) triangular, not or scarcely exceeding the cerci.

7. Large species (exceeding $25 \mathrm{~mm}$.) . . . P. grandis, Sauss.

7'. Smaller species.

8. Supra-anal lamina ( $̛$ ) with three or more spines on either side before the apex.

9. Supra-anal lamina, (ठ̃) scarcely emarginate at apex, (q) shorter than its breadth at base . . . . 9'. Supra-anal lamina, (ô) deeply emarginate at apex, (q) longer than its breadth at base.

8'. Supra-anal lamina

$P$. analis, Sauss.

?P. pseudatrata, Tepp. (ठ) not spined . . P. aterrima, Er.

6'. Supra-anal lamina, (ठ) triangular, (q) triangular and considerably exceeding the cerci.

7. Lateral margins of 7 th abdominal tergite serrate or denticulate.

8. These margins denticulate . . . . P.ferox, sp. n.

8 . These margins serrate.

9. Lateral margins of 6 th abdominal tergite serrate. .

$9^{\prime}$. Lateral margins of 6 th abdominal tergite not serrate

P. melanaria, Er.

P. armata, Tepp.

P. rufofusca, Tepp.

7 . Lateral margins of 7 th abdominal tergite not serrate. 
8. Lateral margins of supra-anal lamina (ð) serrate or minutely denticulate.

9. Posterior angle of 9 th abdominal tergite bispinous . P. bifida, Sauss.

9'. Posterior angle of 9 th abdominal tergite not bispinous.

8'. Lateral margins of supra-anal lamina (o) not serrate nor denticulate.

9. Large species (exceeding $30 \mathrm{~mm}$.$) . P$. invisa, Walk.

9'. Small species . . P. consobrina, Sauss.

5'. Vertex of head orange-rufous P. ruficeps, Shelf.

4'. Thoracic tergites transversely seriate-punctate . $\cdot$. $\cdot$.

3'. Dorsal surface distinctly scabrous.

4. Lateral margin of 7 th abdominal tergite not serrate . . . .

$4^{\prime}$. Lateral margin of 7 th abdominal tergite serrate.

5. Larger (27-31 mm.), antennæ fuscous, lateral margins of thorax not paler than disc . . . . . . .

P. punctata, $\mathrm{Br}$.

P. variolosa, Bol.

P. scabra, Br.

5'. Smaller (19-23 mm.), antennae rufous, lateral margins of thorax paler than disc . P. scabrella, Tepp.

2'. Tegminal rudiments present.

3. Tegminal rudiments on their inner side only half separated from the mesonotum.

4. Coxae margined with testaceous.

5. Lateral margins of 7 th ahdominal tergite not serrate. $P$. coxalis, Walk.

$5^{\prime}$. Lateral margins of 7 th $a b-$ dominal tergite serrate . . P. biglumis, Sauss.

4'. Coxae not margined with testaceous.

5 Legs bright rufous . . . P. rufipes, sp. n. 
5'. Legs piceous or dark castaneous.

6. Small species (less than $16 \mathrm{~mm}$.).

7. 7 th abdominal tergite with pasterior margin subsinuate . . .

P. biloba, Sauss.

$7^{\prime} .7$ th abdominal tergite with posterior margin not subsinuate . . P. perplexa, sp. n.

6'. Larger species . . . P. curiosa, Shelf.

3 '. Tegminal rudiments on their inner side completely separated from the mesonotum.

4. An orange spot on each side of the 7 th abdominal tergite. .

$4^{\prime}$. No orange spots on the 7 th abdominal tergite.

5. Apex of tegminal rudiments obliquely truncate . . .

5 '. Apex of tegminal rudiments tapering.

6. Coxae bordered with flavotestaceous.

7. Castaneous, robust species

7'. Piceous, narrower and

smaller. . . . . P. obscura, Tepp.

6'. Coxae unicolorous.

7. Meso- and meta-notum minutely scabrous. .

P. bicolor, Kirby.

P. novae-seelandiae, $\mathrm{Br}$.

P. castanea, Br.

P. scabriuscula, Tepp.

7 '. Meso- and meta-notum smooth, nitid, with shallow punctures.

8. Small species (14 mm.) P. rufoterminata, Br.

8'. Larger species.

9. Castaneous . . P. pseudocastanea, Tepp.

9.' Piceous.

10. Metanotum with two deeply impressed points . P. ceratodi, Krauss.

10 . Metanotum without these points.

11. Posterior margin of 7 th ab- 
dominal ter-

gite not den-

tate.

12. Legspiceous. P. glabra, Walk.

12 '. Legs castaneous . P. conjuncta, Shelf.

11 '. Posterior margin of 7 th abdominal tergite dentate.

Species incertae sedis P. provisionalis, Tepp.

1'. Not uniform piceous or castaneous.

2. Castaneous or piceous with lateral flavo-testaceous or white borders, abdomen not transversely banded.

3. Tegminal rudiments absent.

4. Pale lateral borders not extending beyond 2nd abdominal tergites, or if extending so far much narrowed.

5. Small species (15 mm.) . . P. inclusa, Walk.

$5^{\prime}$. Larger species.

6. Disc of pronotum not variegated with paler colour . 6 . Disc of pronotum varieP. albomarginata, Br. gated with paler colour.

7. Coxae and femora castaneous; supra-anal lamina (ô) with two large spines at apex and femora testP. brunnea, Tepp.

7'. Coxae and femora test-
aceous, supra-anal lamina (ơ) without large spines at apex $\cdot \cdot \cdot \cdot \dot{ } \cdot$.

4'. Pale lateral borders extending P. variegata, Shelf. tergite.

5. Terminal abdominal sternites not armed with spines . .

5 . Terminal abdominal sternites armed with spines . . . P. spenceri, sp. n.

3'. Tegminal rudiments present.

4. Pale lateral borders not extending on to abdomen or 
represented on abdomen by a series of spots.

5. Pale lateral borders not extending inward to posterior margin of pronotum.

6. Sub-genital lamina (ơ) with a spine at base of genital styles . . . P. soror, Br.

$6{ }^{\prime}$. Sub-genital lamina ( $\left.ో\right)$ without such spine.

7. Posterior tibiae of $\hat{o}$ expanded and flattened . P. semivitta, Walk.

7'. Posterior tibiæ of of not expanded and flattened.

5'. Pale lateral border extending inward to posterior margin of pronotum . . . .

4'. Pale lateral borders extending on to abdomen.

5. Pale lateral borders not extending beyond 5th abdominal tergite . . . .

5 '. Pale lateral borders extending to 7 th abdominal tergite.

Species incertae sedis

$$
\text { P. communis, Tepp. }
$$

P. subbifasciata, Tepp.

P. liturata, Sauss.

P. circumducta, Walk. P. 6-guttata, Walk.

P. balteata, Tepp.

P. latizona, Tepp.

2'. Ferruginous or transversely banded.

3. Tegminal rudiments absent.

4. Posterior angles of 9th abdominal tergite rounded. . . $P$. coolgardiensis, Tepp.

4 '. Posterior angles of 9 th abdominal tergite spiniform . . P. aposematica, sp. n.

3'. Tegminal rudiments present . . P. hartmeyeri, Shelf. Species incertae sedis . . . . . P. zebra, Tepp.

1. P. grandis, Sauss.

Polyzosteria melanaria, var. grandis, Saussure, Mém.

Soc. Sc. Phys. Nat. Genève, xxiii, p. 110 (1873).

This is a distinct species; though the form of the supraanal lamina ( $\delta$ ) is almost the same as in melanaria, the margins of the abdominal tergites are more scabrous, the 
stigmatic dots are more prominent, the coxae are not bordered with testaceous, and the size is much larger.

Victoria, Melbourne (Geneva Mus., type), Western districts (Adelaide Mus.); S. Australia, Adelaide (Oxford Mus.).

2. P. melanaria, Er. (Pl. VII, figs. $3 a, 3 b, 4$.)

Periplaneta melanaria, Erichson, Arch. Naturg., viii, p. 247 (1842.)

There has been some confusion over this and the following species. I am much indebted to Dr. Th. Kuhlgatz for comparing specimens with Erichson's type in the Berlin Museum; the following is a description of the species :-

Piceous, nitid, impunctate. Body depressed and rather narrow. Antero-lateral margins of pronotum very slightly incrassated. Antennae piceous in basal third, remainder rufo-castaneous. Tegminal rudiments absent. Supra-anal lamina, $(\delta)$ trigonal with 3-4 pairs of lateral spines, apex slightly emarginate and more or less rufo-fimbriate, $(q)$ triangular, cucullate, broader at base than its length, apex emarginate, the notch being rounded, margins dentate. Sub-genital lamina (d) quadrate, posteriorly widely emarginate, a minute spine at the base of the genital styles which are slender and acuminate. Cerci longer than the supra-anal lamina in $\delta$, of equal length in + . Coxæ bordered with testaceous. Tibiae and tarsi dark castaneous or piceous.

Length (of types) $25-30.5 \mathrm{~mm}$., (q types) $28-28.5 \mathrm{~mm}$. ; pronotum $7 \mathrm{~mm} . \times 10 \mathrm{~mm}$.

Tasmania (Berlin Mus., types; Oxford Mus.).

3. P. analis, Sauss.

Polyzosteria analis, Saussure, Rev. Zool. (2), xvi, p. 306 (1864).

Polyzosteria melanaria, Brunner von Wattenwyl, Nouv. Syst. Blatt., p. 210 (1865).

Periplaneta invisa, Walker, Cat. Blatt. Brit. Mus., p. 137 (1868) (ô only).

Periplaneta ruficornis, Walker, Cat. Derm. Salt. Brit. Mus. V. Suppl. Blatt., p. 38 (1871).

This is the mainland representative of melanaria and it may be necessary eventually to merge it in that species. 
It differs in the following details which, though small, appear to be constant:-

Supra-anal lamina, ( $\sigma^{\hat{)}}$ with apex rather deeply though narrowly notched, the spines scarcely projecting but curved round close to the lateral margins, $(q)$ longer than breadth at base, apical emargination $\mathbf{V}$-shaped, the apex of the $\mathbf{V}$ filled up by membranous tissue. Cerci shorter, tibiae and tarsi brighter castaneous.

New South Wales (Oxford Mus.); Tarangower (Vienna Mus.); Victoria, Narre Warren (Melbourne Mus.); Western Australia, Swan River (British Mus.); "BomBAY” (British Mus. type of ruficornis).

The type of analis appears to be lost; ruficornis is absolutely identical with specimens in the Melbourne Museum which differ only from Oxford Museum examples in the castaneous margins to the thoracic tergites, castaneous abdominal disc and brighter castaneous tibiae and tarsi; these are mere colour varieties structurally identical with uniformly piceous specimens. The locality Bombay is probably erroneous or the unique specimen was an accidental importation from Australia. If it is eventually proved that analis, Sauss., is strictly conspecific with melanaria, Er., then ruficornis, Walk., must be applied to this species.

4. P. pseudatrata, Tepp.

Platyzosteria pseudatrata, Tepper, Tr. R. Soc. S. Australia, xvii, p. 86 (1893).

Known to me only from the description, which applies equally well to $P$. melanaria and $P$. analis.

Central Australia (Adelaide Mus., type).

5. P. aterrima, Er. (Pl. VII, figs. 5 and 6.)

Periplaneta aterrima, Erichson, Arch. Naturg., viii, p. 248 (1842).

Periplaneta glabra, Tepper, Tr. R. Soc. S. Australia, xvii, p. 107 (1893).

Syntomaptera tepperi, Kirby, Ann. Mag. Nat. Hist. (7), xii, p. 374 (1903).

Specimens of Syntomaptera glabra determined by Tepper in the Melbourne Museum are indistinguishable from $P$. aterrima, Er. I am again indebted to Dr. Kuhlgatz for 
help in determining this species and for sketches (reproduced here) of Erichson's types. The species may be re-described as follows:-

Piceous, nitid, impunctate, rather depressed. Antennae rufous, except a few basal joints which are piceous. Tegminal rudiments absent. Supra-anal lamina, ( $\delta$ ) sub-quadrate, exceeded by the cerci and sub-genital lamina, posterior margin scarcely emarginate, angles not rounded, fimbriate, margins not serrate, $(q)$ trigonal, rather shorter than cerci, apex very slightly emarginate, margins serrate.

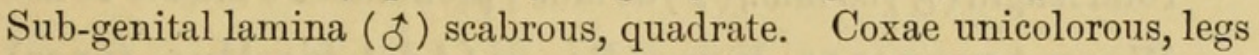
piceous.

Length (type of) $12 \mathrm{~mm}$., (type \&) $16 \mathrm{~mm}$.; pronotum $4 \mathrm{~mm}$. $\times 6 \mathrm{~mm}$.

Tasmania (Berlin Mus., types; Oxford Mus.; Vienna Mus.); New South Wales, Sydney ( $W . W$. Froggatt); Victoria (Melbourne Mus.); South Australia, Northern territory (Adelaide Mus.).

\section{P.ferox, sp. n. (Pl. VII, figs. $7 a, 7 b$.}

§. Piceous, nitid, impunctate, laterally finely scabrous. Lateral margins of thoracic tergites slightly incrassated. Tegminal rudiments absent. Angles of abdominal tergites 5-9 produced as acute spines, lateral margins of tergites 6 and 7 strongly denticulate. Supra-anal lamina sharply triangular, apex terminating in two spines, margins serrate. Cerci short, acuminate. 6th and 7th sternites with a complete row of spines on their posterior margins, these spines on the 4 th and 5th sternites confined to the lateral parts of the posterior margins. All the sternites finely tuberculate laterally. Sub-genital lamina quadrate, scabrous, genital styles stout, spiniform, exceeding the cerci in length. Legs unicolorous, piceous.

Total length $33 \mathrm{~mm}$; pronotum $8 \mathrm{~mm} . \times 12 \mathrm{~mm}$.

Central Australia (Spencer-Gillen Expedition), (Melbourne Mus., type; Oxford Mus.).

\section{P. armata, Tepp. (Pl. VII, figs. 8, 9.)}

Platyzosteria armata, Tepper, Tr. R. Soc. S. Australia, xvii, p. 84 (1893).

Dark castaneous, nitid, minutely punctate, laterally finely scabrous. Antennae rufous, except for castaneous basal joint. Pronotum with impressions and inconspicuous rugosites. No tegminal rudiments. TRANS. ENT. SOC. LOND. 1909.-PART II. (MAY) T 
Angles of abdominal tergites 6-8 produced as blunt spines. Lateral margins of tergites 6 and 7 denticulate-serrate. Supra-anal lamina, (ठ) sharply triangular terminating in two spines, each with a small spine at its base and a smaller one further back, $(q)$ triangular, apex deeply cleft, lateral margins with 7 teeth. Sub-genital lamina (ठ) quadrate. Posterior margin faintly emarginate, scabrous, genital styles stout, acuminate, slightly incurved. Disc of abdomen beneath piceous, scabrous. Coxae and femora rufo-castaneous, tibiae castaneous.

Total length (ô) $35 \mathrm{~mm}$., ( $q$ ) $36 \mathrm{~mm}$.; pronotum $9.5 \mathrm{~mm} . \times 16 \mathrm{~mm}$.

West Australia, Fraser Range (Adelaide Mus., types); Mt. Robinson, Coolgardie (Michaelsen and Hartmeyer), (Hamburg Mus.; Oxford Mus.).

8. P. rufofusca, Tepp.

Platyzosteria rufofusca, Tepper, t. c., p. 84 (1893).

Unknown to me, except from the description. The form of the supra-anal lamina in the + appears to distinguish it from the preceding species.

South Australia, Gilbert River (Adelaide Mus., type).

9. P. bifida, Sauss. (Pl. VII, fig. 10.)

Polyzosteria bifida, Saussure, Mém. Soc. Sci. Phys.

Nat. Genève, xxiii, p. 110, Pl. X, f. 37 (1873).

The species resembles $P$. invisa, Walk., but is readily distinguished by the form of the supra-anal and sub-genital laminae in the male, the angle of the 9 th tergite moreover is bispinous, a character not met with in other species of the genus.

Queensland (Geneva Mus., type).

There is one example in the Oxford Museum from the Burr collection labelled "Brazil," the locality is evidently incorrectly given.

10. P. atrata, Er. (Pl. VIII, fig. 14.)

Periplaneta atrata, Erichson, Arch. Naturg., viii, p. 248 (1842).

Dr. Kuhlgatz has favoured me with a drawing of the supra-anal lamina of the $\hat{\delta}$ type; it is triangular, emarginate at the apex and serrated laterally, it is consequently very like the supra-anal lamina of $P$. melanaria + . 
The types measure $22-23 \mathrm{~mm}$. in length. Specimens from Melbourne and W. Australia have the thoracic tergites margined with rufo-castaneous and the tibiae partly rufo-castaneous but otherwise appear to be the same as the typical form.

Tasmania (Berlin Mus., types); New South Wales, Tarangower (Vienna Mus.) ; Victoria, Melbourne (Melbourne Mus.); Western Australia, Boorabbin (Michaelsen and Hartmeyer), (Hamburg Mus.; Oxford Mus.).

11. P. invisa, Walk. (Pl. VIII, figs. 15, 16.)

Periplaneta invisa, Walker, Cat. Blatt. Brit. Mus., p. 137 (1868), ( + only).

Piceous, nitid, impunctate, margins of segments rather scabrous. Antennae in basal third piceous, remainder rufo-castaneous. No tegminal rudiments. Abdominal stigmatic dots very distinct.

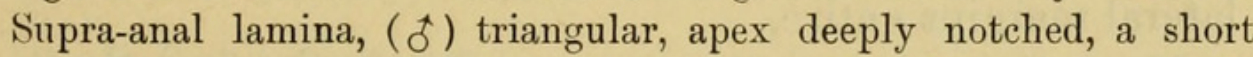
spine on either side of the notch, $(q)$ triangular, longer than in $P$. melanaria, cucullate, apex deeply emarginate, lateral margins 4-dentate. Cerci longer than supra-anal lamina in $\delta^{t}$, shorter in $q$. Subgenital lamina $(\delta)$ quadrangular, scabrous without a spine at base of styles.

Length (of) $33.5 \mathrm{~mm}$., (q) $31 \mathrm{~mm}$; pronotum $8 \mathrm{~mm} . \times 12-13 \mathrm{~mm}$.

Western Australia, Swan River (Oxford Mus., $\hat{\delta}$ type ; British Mus., o type); New SoutH WaLes, Gosford (W. W. Froggatt) (Oxford Mus.).

12. P. consobrina, Sauss.

Polyzosteria consobrina, Saussure, Rev. Zool. (2) xvi, p. 306 (1864).

The identity of this species is very uncertain and the type appears to be lost ; it may be merely a larval form of invisa or identical with atrata, the latter appears to be more likely.

"Australia."

13. P. ruficeps, Shelf.

Platyzosteria ruficeps, Shelford, [in] Fauna Südwest Austral., ii, Lief. 9, Blattidae, p. 134, Pl. XIII, fig. 3 (1909).

Western Australia, Moora (Michaelsen and Hartmeyer), (Hamburg Mus., type). 
14. P. punctata, Br. (Pl. VII, fig. 11, Pl. VIII, figs. $17 a, 17 b$.)

Polyzosteria punctata, Brunner von Wattenwyl, Nouv. Syst. Blatt., p. 211 (1865).

The nearest ally of this species is perhaps aterrima, Er., but punctata is narrower. The seriately arranged shallow punctures on the thoracic tergites are distinctive; the supra-anal lamina is scabrous and the lateral margins of the 7 th abdominal tergite are slightly serrate.

New South Wales, Sydney (Vienna Mus., type).

15. P. variolosa, Bol. (Pl. VII, fig. 13.)

Polyzosteria variolosa, Bolivar, Ann. Soc. ent. France (6) ii, p. 460 (1882).

In the female the supra-anal lamina is produced, cucullate, posteriorly widely emarginate, with acute angles, lateral margins entire.

New Caledonia, Noumea (Bolivar); Île des Pins (Oxford Mus.).

16. P. scabra, Br.

Polyzosteria scabra, Brunner von Wattenwyl, Nouv. Syst. Blatt., p. 213 (1865).

Polyzosteria tarsalis, Walker, Cat. Blatt. Brit. Mus., p. 162 (1868).

New South Wales, Sydney (Vienna Mus., type of scabra), Port Hacking (W. W. Froggatt), (Oxford Mus.); "Australia" (British Mus., type of tarsalis).

17. P. scabrella, Tepp.

Platyzosteria sccbrella, Tepper, Tr. R. Soc. S. Australia, xvii, p. 88 (1893).

This should be readily recognisable from the description; it can be distinguished from the preceding species by its smaller size, the rufous antennae and by the wide emargination of the sub-genital lamina of the $\delta$. The supra-anal lamina of the $\hat{\delta}$ is subquadrate with rounded angles, there are three short teeth on either side near the apex.

South Australia, various localities (Adelaide Mus., types); New South WaLes, Gunnedah ( $W . W$. Froggatt), (Oxford Mus.). 
18. P. coxalis, Walk.

Polyzosteria coxalis, Walker, Cat. Derm. Salt. Brit. Mus. V. Suppl. Blatt., p. 35 (1871).

f. Above rufo-castaneous, abdominal tergites with lateral piceous blotches increasing in size distally. Below piceous with disc of abdomen castaneous. Head rufo-castaneous. Thorax smooth, nitid ; abdominal tergites somewhat scabrous. Tegminal rudiments semiarticulated. Lateral angles of 8th tergite not spinously produced but lobiform as in Cosmozosteria and yellow. Supra-anal lamina quadrate, posteriorly widely emarginate, posterior angles slightly produced, lateral margins serrate. Cerci scarcely exceeding the lamina. Sub-genital lamina quadrate, a minute spine at base of genital styles. Coxae bordered with yellow, femora rufous, tibiae castaneous.

Length $20 \mathrm{~mm}$. ; pronotum $6 \mathrm{~mm} . \times 9 \mathrm{~mm}$.

Bombay (British Mus., type).

19. P. biglumis, Sauss.

Polyzosteria biglumis, Saussure, Rev. Zool. (2) xvi, p. 305 (1864).

Polyzosteria subaptera, Brunner von Wattenwyl, Nouv. Syst. Blatt., p. 212 (1865).

A very variable species both in colour, which ranges from piceous to castaneous, and in size. It can be distinguished by the semi-articulated tegmina, scabrous distal tergites and coxae margined with testaceous.

New South Wales (Oxford Mus.), Sydney (Stockholm Mus.); Victoria, Melbourne (Geneva Mus., type of biglumis); South Australia, Adelaide (Vienna Mus., types of subaptera).

The examples in the Stockholm Museum are much larger than the type, the tegminal rudiments are slightly more articulated and the angles of the 8th abdominal tergites are yellow. The Oxford Museum specimens are intermediate between this form and the typical form.

20. P. perplexa, sp. n.

f. Allied to P. biglumis, Sauss., but differing in the smaller size, rufous antennae, unicolorous coxae and in the almost entire absence of denticulations from the supra-anal lamina. The lateral nargins of the 7 th abdominal tergite are not serrate.

Length $13 \mathrm{~mm}$. ; pronotum $4 \mathrm{~mm} . \times 5 \cdot 8 \mathrm{~mm}$.

Tasmania (Oxford Mus., type). 
This may be merely a local variety of the preceding species and I only regard it provisionally as distinct.

\section{P. rufipes, sp. n.}

Piceous, nitid. A few minute punctures on the thoracic tergites, distal abdominal tergites minutely scabrous, especially in the $\$$. Pro- and meso-notum laterally bordered with rufo-castaneous. Head piceous, antennae rufo-castaneous. Tegminal rudiments semiarticulated. Lateral margins of 7 th abdominal tergite not serrate. Supra-anal lamina, ( $\delta$ ) trigonal, apex truncate, scarcely ernarginate, lateral margins minutely serrate. Cerci exceeding the supra-anal lamina in both sexes. Sub-genital lamina ( $\delta$ ) subquadrate, a spine at the base of each genital style equal to half the length of the style. Coxae not bordered with testaceous, piceous, femora, tibiae and tarsi rufous. Posterior metatarsi rather longer than usual in this genus and armed beneath with a few spines.

Length 11-12.5 mm.; pronotum $4 \mathrm{~mm} . \times 6 \mathrm{~mm}$.

Western Australia (Oxford Mus., types $\hat{\delta}$ and $q$ ).

22. P. biloba, Sauss.

Polyzosteria biloba, Saussure, Mém., Soc. Sci. Phys. Nat. Genève, xx, p. 258, Pl. III, f. 20 (1869).

Known to me from the description only.

Amboina (Geneva Mus., type).

23. P. curiosa, Shelf.

Platyzosteria curiosa, Shelford, [in] Fauna Südwest Austral., ii, Lief. 9, Blattidae, p. 135, Pl. XIII, figs. 11, 12 (1909).

A very remarkable species. A specimen in the Oxford Museum I refer with some doubt to this species, since the legs are rufo-castaneous in colour and the cerci are shorter than the supra-anal lamina.

Western Australia, Northam (Michaelsen and Hartmeyer), (Hamburg Mus., type); “New Holland” (Oxford Mus.).

24. P. bicolor, Kirby.

Melanozosteria bicolor, Kirby, Ann. Mag. Nat. Hist. (7) xii, p. 373 (1903).

A well-marked species.

Torres Straits, Cornwallis Island (British Mus., type ; Oxford Mus., co-type). 
25. P. novae-seelandiae, Br. (Pl. VII, fig. 12.)

Polyzosteria novae-seelandiae, Brunner von Wattenwyl, Nouv. Syst. Blatt., p. 218 (1865).

Periplaneta fortipes, Walker, Cat. Blatt. Brit Mus.,

p. 137 (1868).

This can readily be recognised by the obliquely truncate and strongly punctate tegmina.

New Zealand (Vienna Mus., type of novae-seelandiae; British Mus., type of fortipes; Oxford Mus.).

Two or three species are included in the British Museum collection under the heading fortipes and the type is not indicated; I follow Kirby in regarding the species as synonymous with novce-seelandiae because Walker's New Zealand specimens are undoubtedly identical with Brunner's types. It is not often that the dreary pages of Walker's Catalogues contain any notes of bionomical interest but in his list of specimens of fortipes one is recorded as having been found under the bark of trees devouring bugs. The observation is of interest because it lends some support to the truth of the statement which has been made, though with some scepticism, that the detestable pest, Periplaneta americana, devours the loathsome bed bug.

26. P. castanea, Br. (Pl. VIII, figs. $18 a, 18 b$.)

Polyzosteria castanea, Brunner von Wattenwyl, Nouv. Syst. Blatt., p. 214 (1865).

Platyzosteria avocaensis, Tepper, Tr. R. Soc. S. Australia, xvii, p. 88 (1893).

Platyzosteria exaspera, Tepper, op. cit.'xviii, p. 182 (1894).

I have seen examples of avocaensis and exaspera determined by Mr. Tepper himself; the former is the female of the latter and both are synonymous with castanea, the type of which I have also seen.

$P$. castanea shows distinct affinities with Cosmozosteria, the angles of the abdominal tergites except the 7 th being scarcely produced. The cerci are very short in this species.

New South Wales, Tarangower, Sydney (Vienna Mus., types of castanea; Stockholm Mus. (Godeffroy); Oxford Mus. (W. W. Froggatt)), Avoca (Adelaide Mus., type of avocaensis); VICTORIA (Adelaide Mus., type of exaspera). 
27. P. obscura, Tepp. (Pl. VIII, fig. 19.)

Periplaneta obscura, Tepper, Tr. R. Soc. S. Australia, xvii, p. 107 (1893).

With some doubt I refer two $\hat{\delta} \delta$ in the Hamburg and Oxford Museums to this species.

Piceous, nitid, impunctate except for a few faint punctures on the distal tergites. Antennae fuscous. Tegminal rudiments present, not quite completely articulated. Supra-anal lamina trigonal, apex truncate, rather deeply emarginate, lateral margins entire, faintly concave, exceeded by cerci. Sub-genital lamina quadrate, posterior margin concave, no spine at base of styles. Coxae narrowly bordered with testaceous. Legs piceous.

Length $20 \cdot 1 \mathrm{~mm}$. ; pronotum $5 \cdot 1 \mathrm{~mm} . \times 8 \mathrm{~mm}$.

South Australia, Northern Territory (Adelaide Mus., type); West Australia, Fremantle (Michaelsen and Hartmeyer), (Hamburg Mus.; Oxford Mus.).

The species which was originally described from a $q$ only cannot be recognised with any real certainty.

\section{P. scabriuscula, Tepp. (Pl. VIII, fig. 20.)}

Periplaneta scabriuscula, Tepper, op. cit., p. 108 (1893).

Piceous, nitid, dorsal surface with minute acute tubercles most marked on the middle abdominal tergites. Tegminal rudiments present and completely articulated. Posterior margin of 7 th abdominal tergite sinuate, its posterior angles not very strongly produced. Supra-anal lamina, ( $\delta$ ) quadrate, lateral margins entire, posterior margin concave, rufo-fimbriate, $(q)$ triangular, cucullate, apex truncate, emarginate, lateral margins entire. Cerci exceeding the supra-anal lamina in both sexes. Sub-genital lamina ( $\mathbb{d}^{\star}$ ) quadrate. Coxae not bordered with testaceous ; legs castaneous.

Length $12-17 \mathrm{~mm}$.; pronotum $4.5 \mathrm{~mm} . \times 7-7.5 \mathrm{~mm}$.

South Australia, various localities (Adelaide Mus., types); West Australia (Hamburg Mus. and Oxford Mus. (Michaelsen and Hartmeyer)).

29. P. rufoterminata, Br. (Pl. IX, fig. 30.)

Polyzosteria rufoterminata, Brunner von Wattenwyl, Nouv. Syst. Blatt., p. 219 (1865).

Described from a $q$ only. It is characterised by the rows 
of shallow punctures on the dorsal surface, the rufocastaneous tegminal rudiments, the supra-anal lamina with entire margins and non-emarginate apex.

“New Holland” (Vienna Mus., type).

30. P. pseudocastanea, Tepp.

Platyzosteria pseudocastanea, Tepper, Tr. R. Soc.

S. Australia, xvii, p. 89 (1893).

Known to me only from the description; it appears to differ from castanea, Br., by the unicolorous coxae, and the scabrous supra-anal lamina (ई) with dentate lateral margins and emarginate apex.

S. Australia, Tanunda, Ardrossan (Adelaide Mus., type).

31. P. ceratodi, Kr.

Polyzosteria ceratodi, Krauss, Denkschr. med.-nat. Ges. Jena, viii, p. 751 (1903).

Known to me only from the description.

Queensland, Burnett (Semon) (Jena University Mus., type).

32. P. glabra, Walk.

Periplaneta glabra, Walker, Cat. Blatt. Brit. Mus., p 139 (1868).

๙. Piceous, nitid, impunctate, rather broad. Tegminal rudiments present and completely articulated. Supra-anal lamina quadrate, depressed in middle, lateral margins entire, posteriorly widely emarginate, exceeded by the cerci. Sub-genital lamina widely emarginate, a short blunt spine at the base of the long genital styles. Posterior margin of 7 th abdominal tergite not dentate. Coxae not bordered with testaceous.

Length $20 \mathrm{~mm}$. ; pronotum $7 \mathrm{~mm} . \times 10.9 \mathrm{~mm}$.

“Australia” (British Mus., type).

This species in its general facies closely resembles Cutilia nitida, Br., but can readily be distinguished from that by its tarsal structure. 
33. P. conjuncta, Shelf.

Platyzosteria conjuncta, Shelford, [in] Fauna Südwest Austral., ii, Lief. 9, Blattidae, p. 136 (1909).

This can be distinguished from the preceding by the spines at the posterior angles of the supra-anal lamina (1), from obscura by the form of the sub-genital lamina (ठ)), and from scabriuscula by the absence of scabrous points on the dorsal surface.

West Australia, Collie (Michaelsen and Hartmeyer), (Hamburg Mus., types).

34. P. morosa, Shelf. (Pl. VIII, fig. 21.)

Platyzosteria morosa, Shelford, op. cit., p. 136 (1909).

Distinguished from the preceding by the form of the supra-anal lamina (f) ; the species varies considerably in size.

South Australia (Oxford Mus., types); West Australia, S. Albany, Lion Mill, Mundaring Weir (Michaelsen and Hartmeyer), (Hamburg Mus.).

35. P. provisionalis, Tepp.

Periplaneta provisionalis, Tepper, Tr. R. Soc. S. Australia, xvii, p. 108 (1893).

This species cannot be recognised from the description; some specimens in the Melbourne Museum, identified by $\mathrm{Mr}$. Tepper as provisionalis, are young larvae that cannot be referred with any certainty to this or to any other species of the genus.

South Australia, Mount Bryan East (Adelaide Mus., type).

36. P. inclusa, Walk.

Periplaneta inclusa, Walker, Cat. Blatt. Brit. Mus., p. 140 (1868).

Platyzosteria inclusa, Shelford, [in] Fauna Suidwest Austral., ii, Lief. 9, Blattidae, p. 137, Pl. XIII, fig. 4 (1909).

Piceous above, sometimes variegated with castaneous on the disc of the thorax, nitid, impunctate. Thorax margined laterally with testaceo-hyaline. Head and legs rufous. Antennae rufo-castaneous. No tegminal rudiments. Posterior angles of abdominal tergites 
scarcely produced backwards in $\delta$. Supra-anal lamina, ( $\delta$ ) subquadrate, apex widely emarginate, lateral margins entire, ( $q$ ) cucullate, triangular, apex emarginate, lateral margins entire, exceeded by the cerci. Sub-genital lamina (of) with posterior margin slightly produced.

Total length (of ) $14.8 \mathrm{~mm}$. , (q) $16 \mathrm{~mm}$. ; pronotum $4-4.8 \mathrm{~mm} . \times$ 5-5.8 mm.

West Australia, various localities (British Mus., type ; Oxford Mus.; Hamburg Mus. (Michaelsen and Hartmeyer)).

37. P. albomarginata, Br. (Pl. VIII, fig. 22.)

Polyzosteria albomarginata, Brunner von Wattenwyl, Nouv. Syst. Blatt., p. 212 (1865).

Brunner's description is drawn up from a larval specimen, the following is a description of the adult male :-

Piceous, nitid, impunctate. Antennae rufescent except at base. Thoracic tergites faintly carinate, laterally bordered with flavotestaceous, the borders being outwardly margined rather broadly with piceous. Tegminal rudiments absent. Lateral margin of 7 th abdominal tergite finely serrate. Supra-anal lamina triangular, apex incised, lateral margins serrate. Cerci equal in length to the lamina. Sub-genital lamina quadrate, scabrous, styles stout. Legs rufo-castaneous.

Length $34 \mathrm{~mm}$; pronotum $9 \mathrm{~mm} . \times 13.8 \mathrm{~mm}$.

New South Wales, Sydney (Vienna Mus., type); West Australia, Coolgardie (Hamburg Mus.), Kalgoorlie (coll. Froggatt.)

38. P. brunnea, Tepp.

Platyzosteria albomarginata, var. brunnea, Tepper, Tr.

R. Soc. S. Australia, xvii, p. 86 (1893).

This appears to be quite distinct from the precediug, but I have seen no examples.

S. Australia, Gilbert River, Kangaroo Is.; Central Australia, Barrow range (Adelaide Mus., types).

39. P. variegata, Shelf.

Platyzosteria variegata, Shelford, [in] Fauna Südwest Austral., ii, Lief. 9, Blattidae, p. 137, Pl. XIII, fig. 14 (1909). 
Distinguished from the two preceding species, its nearest allies, by the form of the supra-anal lamina (ई).

West Australia, Boyanup (Michaelsen and Hartmeyer), (Hamburg Mus., type).

40. P. obscuripes, Tepp. (Pl. VIII, fig. 23.)

Drymaplaneta obscuripes, Tepper, Tr. R. Soc. S. Australia, xvii, p. 112 (1893).

I have seen no mature examples of this, and strongly suspect it of being the larva of one of the three preceding species. The larval condition of the $q$ subgenital valves is employed by Tepper as one of the diagnostic characters of his genus Drymaplaneta!

South Australia, West coast; West Australia, Fraser range (Adelaide Mus., types), Swan river (Oxford Mus.).

41. P. spenceri, sp. n.

§. Piceous, nitid, impunctate. Disc of abdomen beneath rufocastaneous. Margined all round continuously with flavo-testaceous, outlined outwardly with piceous; the supra-anal lamina and cerci piceous or castaneous. Tegminal rudiments absent. Posterior angles of all the abdominal tergites very acutely produced, especially the 8th. Lateral margins of 6 th tergite serrate, of 7 th denticulate. Supra-anal lamina acutely triangular, terminating in a pair of diverging spines, lateral margins denticulate. Cerci not exceeding the supra-anal lamina. Terminal sternites laterally finely tuberculate. Posterior margin of 6 th abdominal sternite strongly denticulate, posterior margins of the two preceding sternites laterally with smaller denticles. Sub-genital lamina small, sub-quadrate, styles very stout, incurved, equal to the cerci. Coxae narrowly bordered with testaceous. Legs piceous.

Length $28 \mathrm{~mm}$; pronotum $7 \mathrm{~mm} . \times 10 \mathrm{~mm}$.

Central Australia (Spencer-Gillen expedition), (Melbourne Mus., type; Oxford Mus., co-type).

42. P. soror, Br. (Pl. VIII, figs. 24a, 24b.)

Polyzosteria soror, Brunner von Wattenwyl, Nouv. Syst. Blatt., p. 219 (1865).

Periplaneta semicincta, Walker, Cat. Blatt. Brit. Mus., p. 140 (1868).

This is the insular form of the next species; it can be 
distinguished by its smaller size, more convex shape, the outer border of the flavo-testaceous thoracic margins not distinctly margined with castaneous, the genital styles with a spine at their base and by the supra-anal lamina (o) being less emarginate at the apex. The species varies in size, New Caledonian examples being the smallest, Bornean examples the largest.

Amboina (Vienna Mus., type of soror); Ceram (British Mus.); Navigator's Is. (Brit. Mus., type of semicincta); New Caledonia (Oxford Mus.); New Hebrides (Melbourne Mus.); Tonga (Stockholm Mus.); Borneo (Oxford Mus.); Formosa (British Mus.).

\section{P. communis, Tepp. (Pl. VIII, figs. 25a, 25b.)}

Drymaplaneta communis, Tepper, Tr. R. Soc. S. Australia, xvii, p. 110 (1893).

Methana antipodum, Brancsik, Jahresh. Ver. Trencsin. Com. xix-xx, p. 58, Pl. I, fig. 4 (1897).

Queensland (Oxford Mus.); South Australia, various localities (Adelaide Mus., type of communis ; Oxford Mus., type of antipodum); West Australia, Swan River (Oxford Mus.).

44. P. semivitta, Walk. (Pl. VIII, figs. $26 a$ to $26 f$.)

Periplaneta semivitta, Walker, Cat. Blatt. Brit. Mus., p. 143 (1868).

Piceous or dark castaneous above, nitid, impunctate. Thoracic tergites laterally bordered with clear flavo-testaceous, outwardly narrowly margined with castaneous. Head testaceous, a castaneous band on vertex and a castaneous blotch on frons, antennae rufocastaneous. Maxillary palpi ( $\left.\delta^{\star}\right)$ with 1st and 2nd joint swollen. Labrum sub-bilobate. Tegminal rudiments present, subtruncate at apex. 1st abdominal tergite $(\delta)$ with a circular gland-opening fringed with rufous setae.* Supra-anal lamina, ( ${ }^{*}$ ) quadrate, angles acute but not produced, posterior margin slightly emarginate, lateral margins entire, $(q)$ cucullate, triangular, apex deeply notched. Subgenital lamina $\left(\delta^{t}\right)$ trapezoidal, produced, apex widely emarginate, styles placed sub-laterally. Cerci surpassing the supra-anal lamina in both sexes. Coxae testaceous, blotched with castaneous. Femora rufo-castaneous, anterior pair paler; tibiae castaneous. Posterior tibiae $(\delta)$ very stout, flattened and expanded.

Total length (ơ) 24, , (q) $25 \mathrm{~mm}$.; pronotum $7 \mathrm{~mm} . \times 9 \mathrm{~mm}$.

* This is frequently hidden under the metanotum. 
Western Australia, Swan River (British Mus., type); South Australia, various localities (Michaelsen and Hartmeyer), (Hamburg Mus.; Oxford Mus.).

This is a somewhat anomalous form as shown by the curious secondary sexual characters of the male.

\section{P. sub-bifasciata, Tepp.}

Drymaplaneta sub-bifaseiata, Tepper, Tr. Roy. Soc. S. Australia, xvii, p. 112 (1893).

Evidently described from a larva. There is an adult o in bad condition and without label in the Oxford Museum; in this the lateral yellow border of the thoracic tergites is interrupted at the mesonotum by the tegminal rudiments, which are piceous. The species is readily recognisable by the production, along the hind-margins of the pro- and meta-notum, of the lateral yellow border.

South Australia, Northern territory (Adelaide Mus., type).

46. P. liturata, Sauss.

Polyzosteria liturata, Saussure, Mém. Soc. Sci. Phys. Nat. Genève, xxiii, p. 108, Pl. X, fig. 36 (1873).

Known to me only from the description.

New Georgia (Geneva Mus., type).

47. P. circumducta, Walk.

Periplaneta circumducta, Walker, Cat. Blatt. Brit. Mus., p. 143 (1868).

Drymaplaneta submarginata, Tepper, Tr. R. Soc. S. Australia, xvii, p. 111 (1893).

Closely allied to $P$. soror, $\mathrm{Br}$., but the flavo-testaceous border runs completely round the body including the anterior margin of the pronotum and so much as is visible of the 8th abdominal tergite. Supra-anal lamina (o) quadrate, margins entire, posteriorly not emarginate. A small spine at base of styles.

? LOC. (British Mus., type of circumducta); SoutH Australia, Kangaroo Is., Mount Lofty range (Adelaide Mus., type of submarginata). 
48. P. sexguttata, Walk.

Periplaneta sexguttata, Walker, Cat. Blatt. Brit. Mus., p. 141 (1868).

This is a very young larva.

“Australia" (British Mus., type).

49. P. balteata, Tepp.

Platyzosteria balteata, Tepper, Tr. R. Soc. S. Australia, xvii, p. 91 (1893).

I have been quite unable to recognise this and the next species; their generic position is problematical.

50. P. latizona, Tepp.

Platyzosteria latizona, t.c., p. 92 (1893).

South Australia, Mount Bryan East (Adelaide Mus., type).

51. P. coolgardiensis, Tepp. (Pl. VIII, fig. 27.)

Platyzosteria coolgardiensis, Tepper, op. cit., xix, p. 159 (1894).

đ. Rufo-testaceous, impunctate, opaque. Disc of thoracic tergites, a band on each abdominal tergite, disc of abdomen beneath, tibiae and tarsi castaneous or rufo-castaneous. Tègminal rudiments absent. Posterior angles of abdominal tergites 2-5 scarcely produced, of tergites 6-7 strongly produced, of tergite 9 sub-lobiform. Lateral margins of 6 th and 7 th abdominal tergites finely serrate. Supra-anal lamina triangular terminating in two slender spines, barely exceeding the cerci in length. Subgenital lamina trapezoidal, posteriorly very slightly emarginate, styles stout, acuminate. Posterior metatarsi not spined beneath ; its pulvillus apical.

Length $24 \mathrm{~mm}$.; pronotum $6 \mathrm{~mm} . \times 10 \mathrm{~mm}$.

West Australia, Coolgardie (Adelaide Mus., type), Kalgoorlie ( $W . W$. Froggatt), (Oxford Mus.).

The above description is drawn up from a specimen determined by Mr. Tepper and kindly presented to the Oxford Museum by Mr. Froggatt. The species is an anomalous one, but seems to fit sufficiently into the genus Platyzosteria. 


\section{P. aposematica, sp. n. (Pl. IX, fig. 29.)}

१. Pale ferruginous above, disc of pro- and mesonotum, posterior margins of abdominal tergites, 9th tergite, supra-anal lamina and cerci, piceous. Abdomen beneath piceous with the disc castaneous ; legs castaneous. Tegminal rudiments absent. Lateral margins of 6th and 7th abdominal tergites serrate, posterior angles strongly produced. Posterior angles of 9th tergite spiniform. Supra-anal lamina triangular, apex notched, lateral margins denticulate. Cerci of equal length with the lamina. Ultimate and penultimate sternites laterally scabrous, posterior margins laterally finely dentate.

Length $40 \mathrm{~mm}$.; pronotum $9 \cdot 6 \mathrm{~mm} . \times 13 \mathrm{~mm}$.

Central Australia (Spencer-Gillen Expedition), (Melbourne Mus., type).

It is rather remarkable that the three Central Australian species described here should show the same tendency to spinosity of the terminal abdominal segments.

53. P. hartmeyeri, Shelf.

Platyzosteria hartmeyeri, Shelford [in] Fauna Südwest Austral., ii, Lief. 9, Blattidae, p. 138 (1909).

West Australia, Boorabbin (Hamburg Mus., type).

54. P. zebra, Tepp.

Polyzosteria zebra, Tepper [in] Horn Exped. Centr. Australia, ii, p. 362 (1896).

I am unable to determine the correct systematic position of this species; the original description is quoted herewith :-

" $q$. Yellow, banded with piceous, stout. Vertex, a band between and below the antennae, base of clypeus, and a longitudinal stripe reddish-piceous. Antennae and palpi reddish. Pronotum scarcely hooded, not much reflexed laterally, almost smooth, shining, disc indistinctly impressed with very faint dark spots; hind angles subacute; hind margin concave. Meso- and metanotum similar, each side with small shallow pits, a dark band rather broad in the middle and convex behind, short; hind margin of metanotum slightly and angularly produced in the middle. Abdomen almost smooth, except a few scattered pits, dark basal band narrow, not extending to lateral margin, posterior angles rectangular or shortly produced as a small tooth. Legs bicolorous; coxae pale testaceous, 
anterior border, base and a short stripe in the middle reddishbrown; femora with inner side pale testaceous, remainder reddish ; tibiae and tarsi reddish-piceous; arolia large. Abdomen ventrally pale yellowish, each segment with a narrow dark basal band extending to lateral margin. Cerci as long as lamina, slender, pale yellow, terminating in a short spine.

“Total length $35 \mathrm{nim}$. ; pronotum $9 \mathrm{~mm} . \times 19 \mathrm{~mm} . "$

Central Australia.

\section{Genus 4. Leptozosteria, Tepp.}

Leptozosteria, Tepper, Tr. R. Soc. S. Australia, xvii, p. 96 (1893).

Characters. "Body very flat and thin, elongate. Integument soft. Supra-anal lamina of male triangular, terminating in an acute apical spine. Colour pale with dark bands."

The only species of this genus which I have seen is L. secunda, Tepp., and that is undoubtedly conspecific with Cutilia triangulata, Br. (q.v.). The only important character in Tepper's generic diagnosis is the form of the male supra-anal lamina, and as there are many objections to founding new genera on male secondary sexual characters alone, I expect that it will eventually be necessary to sink Leptozosteria as a synonym of Platyzosteria or of Cutilia.

1. L. prima, Tepp.

Leptozosteria prima, Tepper, t. c., p. 96 (1893).

Central Australia, Cordilho Downs (Adelaide Mus., type).

\section{Genus 5. Cutilia, Stål.}

Cutilia, Stål, Oefv. Vet. Akad. Förh., xxxiv (10), p. 36 (1877).

Characters. Closely allied to Platyzosteria, Br., but the posterior metatarsus long and biseriately spined beneath, its pulvillus apical; remaining tarsal joints unarmed beneath, their pulvilli occupying the entire joints. Tegminal rudiments present. In all but one species the posterior angles of the distal abdominal tergites strongiy produced backwards. Supra-anal lamina (ơ) quadrate.

Type of the genus-C. nitida, Br.

Stål founded the genus on C. tartarea, Stål, which is synonymous with $C$. nitida, $\mathrm{Br}$. The genus is a link

TRANS. ENT. SOC. LOND. 1909.-PART II. (MAY) U 
between the Polyzosteria-group and the Blatta-group, on account of the tarsal structure (Pl. IX, fig. 40b).

\section{KEY TO THE SPECIES.}

1. Piceous or castaneous.

2. Piceous. Legs piceous. Broad convex species . . . . . . . . . C. nitida, Br.

2'. Castaneous. Legs testaceous. Narrow, sub-depressed species

C. melanesiae, sp. n.

1'. Testaceous or ferruginous.

2. Disc of pronotum with three fuscous markings arranged in a triangle. . .

2'. Pronotum with more or less distinct fuscous lateral vittae.

3. Species exceeding $13 \mathrm{~mm}$. in length.

4. Posterior angles of distal abdominal

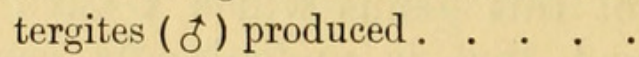

4'. Posterior angles of distal abdominal tergites (ô) not produced . . .

3 . Species not exceeding $13 \mathrm{~mm}$. in length .

C. triangulata, Br.

C. heydeniana, Sauss.

C. sedilloti, Bol.

C. brunni, Alfk.

1. C. nitida, $\mathrm{Br}$.

Polyzosteria nitida, Brunner von Wattenwyl, Nouv. Syst. Blatt., p. 214 (1865).

Periplaneta polita, Walker, Cat. Blatt. Brit. Mus., p. 139 (1868).

Cutilia tartarea, Stål, Oefv. Vet. Akad. Förh., xxxiv (10), p. 36 (1877).

? Blatta aterrima, Escholtz, Entomographien, p. 89 (1822).

This species, which is very variable in size, has a wide range outside Australia; the record of its occurrence in Australia is doubtful. I do not know whether Escholtz's type is preserved and his species may not perhaps have the slightest affinity with nitida, for the description is too brief for it to be possible to judge of that.

Formosa (British Mus., type of polita); Philippines (Stockholm Mus., type of tartarea ; British Mus.); Bonneo (Oxford Mus.; Paris Mus.); Ternate (British Mus.); Amborna (Vienna Mus., type of nitida; Oxford Mus.); New Guinea (Oxford Mus.; Brussels Mus.; Melbourne Mus.); 
Torres Straits (British Mus.); New South Wales, Sydney (Oxford Mus.).

\section{C. melanesiae, sp. n.}

f Above castaneous, nitid, impunctate. Head, legs and antennae bright testaceous. A broad castaneous stripe down the middle of the face. Tibial spines castaneous. Posterior borders of thoracic tergites slightly produced in the middle. Posterior angles of abdominal tergites moderately produced. Supra-anal lamina trigonal, margins entire, apex truncate, fimbriate, scarcely emarginate, considerably exceeded by the cerci. Sub-genital lamina subquadrate, styles moderate, a well-marked spine at the base of each. Posterior metatarsus exceeding the succeeding joints in length.

Length $19 \mathrm{~mm}$. ; pronotum $6 \mathrm{~mm} . \times 8 \mathrm{~mm}$.

Torres Straits (British Mus., type).

Readily distinguished by the bright testaceous legs.

3. C. triangulata, Br.

Polyzosteria triangulata, Brunner von Wattenwyl, Ann. Mus. Civ. Genova, ser. $2 \alpha$, xiii, p. 33 (1893).

Leptozosteria secunda, Tepper, Tr. R. Soc. S. Australia, xviii, p. 183 (1894).

Polyzosteria triangulata, Krauss, Denkschr. med.nat. Ges. Jena, viii, p. 750, Pl. LXVII, fig. 1 (1903).

Stâl in 1877 quotes this species as belonging to the genus Cutilia but gives no description of it. Brunner in a footnote (l.c.) alludes to the species but does not give a detailed diagnosis of it; if his remarks on the species beginning- "le metatarse un peu plus long que les autres articles réunis," etc. etc., are reckoned as a diagnosis then the name triangulata can stand, but if not then this name must be replaced by secunda, Tepp. This is a matter for priority-cranks to wrangle over, but it is not of the least importance. As Krauss gives a good description and figure of the species under the name triangulata and as this name is more appropriate than secunda I have no hesitation in adopting it.

Queensland, Rockhampton (Vienna Mus., type), Bowen (Godeffroy) (Stockholm Mus.), Cooktown (Adelaide Mus., type of secunda), Endeavour river (Oxford Mus.); Thursday Is. (Jena University Mus.). 
4. C. heydeniana, Sauss.

Periplaneta heydeniana, Saussure, Rev. Zool. (2) xvi, p. 317 (1864).

Polyzosteria heydeniana, Saussure, Mém. Soc. Sci. Phys. Nat. Genève, xx, p. 256 (1869).

Periplaneta marginifera, Walker, Cat. Blatt. Brit. Mus., p. 144 (1868).

West Australia, King George's Sound (British Mus., type of marginifera; Oxford Mus.; Geneva Mus., type of heydeniana; Paris Mus.), Albany (Hamburg Mus.).

5. C. sedilloti, Bol.

Polyzosteria sedilloti, Bolivar, Ann. Soc. Ent. France (6) ii, p. 459 (1882).

In the $\hat{\delta}$ the posterior angles of the posterior abdominal tergites are rounded and they are not much produced in the ?.

New Zealand (coll. Bolivar, type; Oxford Mus.).

6. C. brunni, Alfk.

Platyzosteria brunni, Alfken, Abh. Ver. Bremen, xvii, p. 142 (1901).

Known to me only from the description. It is apparently to be distinguished by its small size, but it must be noted that sedilloti itself varies considerably in size, a specimen in the Oxford Museum from the North island of New Zealand being smaller than specimens from the South island.

Снатнам Is. (Bremen Mus., type).

Genus 6. ZonioplocA, Stål.

Zonioploca, Stål, Bih. Svensk. Akad. ii (13), p. 13 (1874). Knephasia, Tepper, Tr. R. Soc. S. Australia, xvii, p. 99 (1893).

Characters. Ocelli absent. Lateral margins of pronotum incrassated. Dorsal surface granulate, or with shallow punctures. Tegminal rudiments absent. Posterior angles of abdominal tergites 5-7 strongly produced. Supra-anal lamina, (đ) quadrate, angles obtuse, lateral margins entire, ( $q)$ triangular, apex emarginate. Sub-genital lamina ( $\left.\sigma^{\star}\right)$ trapezoidal, styles lateral. Posterior 
metatarsus unarmed beneath, equal to the remaining joints in length, its pulvillus apical.

Type of the genus-Z. alutacea, Stål.

\section{KEY TO SPECIES.}

1. Dorsal surface granulate; smaller species.

2. Tibiae unicolorous, testaceous . . . .

2 '. Tibiae castaneous on dorsal aspect, testaceous on ventral aspect.

3. Pro- and mesonotum with lateral fuscous vittae, abdomen above transversely banded with fuscous and olivaceous . . . . . . .

3'. Pro- and mesonotum without lateral fuscous vittae, abdomen above unicolorous, testaceous . . . .

$1^{\prime}$. Dorsal surface with large shallow punctures ; robust species.

Z. medilinea,Tepp.

Z. alutacea, Stål.

Z. pallida, Shelf.

2. Femora and tibiae purple . . . . Z. eastii, Tepp.

2'. Femora and tibiae rufo-testaceous . . Z. robusta, sp. n.

1. Z. medilinea, Tepp.

Knephasia medilinea, Tepper, Tr. R. Soc. S. Australia, xvii, p. 100 (1893).

Readily distinguished by the dark median line, extending from the posterior border of the pronotum to near the apex of the abdomen.

Victoria, Lillimur; South Australia, Sedan, Northern territory (Adelaide Mus., types); WEST Australia, Mt. Robinson (Hamburg Mus.; Oxford Mus.).

2. Z. alutacea, Stål.

Zonioploca alutacea, Stål, Bih. Svensk. Akad. ii (13), p. 13 (1874).

Platyzosteria ardrossanensis, Tepper, Tr. R. Soc. S. Australia, xvii, p. 92 (1893).

Tepper's description of ardrossunensis corresponds perfectly with alutacea, the type of which has been kindly lent to me by Dr. Y. Sjöstedt of Stockholm.

"Australia" (Stockholm Mus., type of alutacea); Queensland (Oxford Mus.); SouTh Australia, Ardrossan (Adelaide Mus., type of ardrossanensis); WEST Australia, Albany (Deutsche Entom. National Museum). 
3. Z. pallida, Shelf. (Plate IX, figs. $28 a$ and 28b.)

Zonioploca pallida, Shelford, [in] Fauna Suidwest Austral. ii, Lief. 9, Blattidae, p. 138, Pl. XIII, fig. 7 (1909).

This species varies considerably in size, in the extent of the granulation of the dorsal surface and some examples are paler than others.

West Australia, various localities (Oxford Mus., types; Hamburg Mus.).

4. Z. eastii, Tepp.

Anamesia eastii, Tepper, Tr. R. Soc. S. Australia, xvii, p. 92 (1893).

Known to me only from the description.

Central Australia (Adelaide Mus., type).

\section{Z. robusta sp. n.}

. Testaceous, nitid. Head castaneous, mouth-parts and antennae testaceous. Dorsum with large shallow punctures, thoracic tergites rugose laterally and with a lateral castaneous vitta, a castaneous spot at the base of the meso- and metanotum in the middle line. The punctures on the abdominal tergites rufo-castaneous ; margins of 6th and 7th tergites very faintly serrate. Supra-anal lamina trigonal, sub-cucullate, apex emarginate. Cerci not exceeding the lamina, slender, flattened. Abdomen beneath impunctate, pale testaceous, penultimate tergite and valves rufous. Legs rufo-testaceous.

Length $35 \mathrm{~mm}$. ; pronotum $10 \mathrm{~mm}$. $\times 16.5 \mathrm{~mm}$.

\footnotetext{
Central Australia (v. Leonhardi), (Senckenberg Mus., type).
}

\section{Genus 7. Cosmozosteria, Stål.}

Cosmozosteria, Stål, Bih. Svensk. Vet. Akad. ii (13), p. 13 (1874).

Characters. Ocelli present. Tegminal rudiments absent. Abdomen broader than thorax. Posterior angles of abdominal tergites 5-6 not, or scarcely produced, of tergite 7, produced. Angles of 9th abdominal tergite lobiform. Dorsal surface of abdomen scabrous. Supra-anal and sub-genital laminæ (o) quadrate. Cerci short. Posterior metatarsus very short, unarmed beneath, its pulvillus occupying the greater part of the joint. 
Mr. R. Shelford's Studies of the Blattidae.

Type of the genus-C. bicolor, Sauss.

The genus is not very well marked off from Platyzosteria but the species here included in it have all a well-marked facies which is quite distinct from that of Platyzosteria species.

\section{KEY TO THE SPECIES.}

1. Unicolorous castaneous, except the angles of 9 th abdominal tergite .

1'. Banded, margined or spotted with ochreous.

2. Posterior margins of thoracic tergites ochreous.

3. Abdominal tergites unicolorous

3'. Abdominal tergites spotted with ochreous.

4. Meso- and metanotum not bordered laterally with ochreous . . . . . . .

4'. Meso- and metanotum bordered laterally with ochreous . . . . .

C. froggatti, sp. n.

C. zonata, Walk.

C. maculimarginata, Tepp.

C. bicolor, Sauss. var.

2'. Posterior margins of thoracic tergites not ochreous.

3. Abdominal tergites with transverse ochreous streaks.

4. Thoracic tergites with triangular lateral ochreous markings. . . . . .

4'. Thoracic tergites laterally banded with ochreous . . C. picta, Tepp.

3'. Abdominal tergites with small lateral ochreous spots.

4. Thoracic tergites with complete lateral borders of ochreous. . . . .

$4^{\prime}$. Thoracic tergites with incomplete lateral borders of ochreous . . . . . C. lateralis, Walk.

1. C. froggatti, sp. n.

$\delta$ and $q$. Uniform castaneous above, except the angles of the 9th abdominal tergite which are orange; margins of thoracic 
tergites sometimes rather paler than the disc. Antennae rufescent. Thoracic tergites smooth, impunctate. Abdominal tergites rather scabrous. Supra-anal lamina, ( $\delta$ ) quadrangular, angles spiniform, deflexed, posterior margin straight, surpassed by sub-genital lamina which is quadrate, posteriorly widely emarginate, angles spiniform, with styles lateral, $(q)$ trigonal, sub-cucullate, apex rounded not emarginate, margins faintly crenulate. Cerci (mutilated in $\hat{\sigma}$ ) barely exceeding the supra-anal lamina $(q)$. Coxae margined with ochreous, posterior metatarsus short.

Length (ô) $25 \mathrm{~mm}$., (q) $27 \mathrm{~mm}$. ; pronotum $8 \mathrm{~mm} . \times 12$ $13 \mathrm{~mm}$.

Queensland, Lolworth (coll. Froggatt, type $\uparrow$ ), Peak Downs (Stockholm Mus., type $q$ ).

The $q$ o $q$ are paler than the male.

\section{C. zonata, Walk. (Pl. IX, figs. 31, 32.)}

Polyzosteria zonata, Walker, Cat. Blatt. Brit. Mus., p. 159 (1868).

Polyzosteria quadrifascia, Walker, t. c., p. 160 (1868). Polyzosteria pectoralis, Walker, t. c., p. 160 (1868).

Platyzosteria trifasciata, Tepper, Tr. R. Soc. S. Australia, xvii, p. 91 (1893).

Piceous (quadrifascia) or castaneous (zonata). Anterior margin of pronotum ochreous (quadrifascia) or unicolorous with dise (trifasciata); posterior margins of thoracic tergites narrowly or broadly (zonata) ochreous. Thoracic tergites minutely punctate with some smooth spaces. Dorsal surface of abdomen scabrous, posterior angles of 2 nd to 5 th tergites not produced, of 6 th slightly produced, of 7th strongly produced, of 9 th lobiform ( $\delta$ ) or spiniform (q) and sometimes orange in colour. Lateral margins of 7 th tergite serrate, more strongly in of than in $q$. Abdomen beneath finely scabrous, lateral margins of 7 th sternite $(\delta)$ denticulate, of 6 th sternite $(q)$ serrate. Supra-anal lamina, $(\hat{f})$ quadrate, posteriorly non-emarginate and rufo-fimbriate, posterior angles produced as strong, deflexed spines, $(q)$ triangular, cucullate, apex emarginate, laterally serrate. Sub-genital lamina (ơ) trapezoidal, posteriorly widely emarginate, exceeding the supra-anal lamina, posterior angles spinously produced, styles lateral. Cerci orange or piceous exceeding the supra-anal lamina $(\delta)$ but not the sub-genital lamina, acutely pointed. Coxae margined with testaceous.

Length (ơ) $21 \mathrm{~mm}$., (q) $25.5 \mathrm{~mm}$.; pronotum $6.5-7.5 \mathrm{~mm}$. $\times 10-13 \cdot 1 \mathrm{~mm}$. 
QueEnsland (British Mus., type of quadrifascia; Oxford Mus.; Melbourne Mus.); South Australia, Northern territory (British Mus., type of pectoralis; Oxford Mus.; Adelaide Mus., type of trifasciata; Melbourne Mus.), Port Essington (British Mus., type of zonata; Oxford Mus).

3. C. maculimarginata, Tepp.

Platyzosteria maculimarginata, Tepper, Tr. R. Soc.

S. Australia, xix, p. 160 (1895).

Known to me only from the description; it may be only a varietal form of the preceding.

N. Queensland (Adelaide Mus., type).

4. C. bicolor, Sauss. (Pl. IX, fig. 33.)

Polyzosteria bicolor, Saussure, Rev. Zool. (2) xvi, p. 307 (1864) ; Mém. Soc. Sci. Phys. Nat. Genève, $\mathrm{xx}$, p. 259 (1869).

Polyzosteria ligata, Brunner von Wattenwyl, Nouv. Syst. Blatt., p. 220 (1865).

Platyzosteria subzonata, Tepper, Tr. R. Soc. S. Australia, xviii, p. 181 (1894).

This is another species that in coloration is very variable; the form subzonata has the posterior margins of the thoracic tergites narrowly bordered with ochreous but is otherwise indistinguishable from the type form. Structurally the species differs from C. zonata, Walk., as follows:- The abdomen is less scabrous, none of the abdominal tergites or sternites are laterally serrate, the posterior angles of the 7 th abdominal tergite are scarcely produced, the supra-anal lamina (ô) has minute, nondeflexed spines at the posterior angles, ( $(q)$ with the margins entire.

"Australia" (Geneva Mus., type of bicolor); QueensLAND (Oxford Mus.), Port Curtis (Vienna Mus., type of ligata), Stradbrooke Is. (coll. Froggatt); VicToria (Adelaide Mus., type of subzonata); New South Wales, Darling river (Oxford Mus.; Melbourne Mus.).

5. C. gloriosa, sp. n.

ๆ. Dark castaneous; thoracic tergites with large triangular flavid blotches situated near their posterior angles. Abdominal 
tergites 1-7 with transverse narrow flavid streaks extending from the outer margins inward, 3 to 4 minute brown spots in each streak.

Dorsal surface minutely shagreened and with large punctures on the meso-, metanotum and abdominal tergites. Posterior angles of 6 th abdominal tergite scarcely produced, of 7 th strongly produced. (Cerci and supra-anal lamina mutilated.) Ventral surface castaneous, apex of valves and margins of coxae flavo-testaceous.

Length $25.2 \mathrm{~mm}$; pronotum $8.9 \mathrm{~mm} . \times 14 \mathrm{~mm}$.

Queensland, Cooktown (Melbourne Mus., type).

The species is allied to C.picta, Tepp., but is I believe quite distinct.

6. C. lateralis, Walk.

Polyzosteria lateralis, Walker, Cat. Blatt. Brit. Mus., p. 154 (1868).

Polyzosteria ferruginea, Walker, t. c., p. 158 (1868).

․ Rufo-castaneous, thoracic tergites minutely shagreened, abdomen above very scabrous. Pronotum on the antero-lateral margins only ochreous, meso- and metanotum with an ochreous spot at the anterior angles. Abdominal tergites 2-6 with small ochreous spots, laterally situated. Posterior angles of tergites 6-7 produced, of 9th tergite lobiform, ochreous. Supra-anal lamina trigonal, lateral margins serrate, apex not emarginate, exceeded by the cerci which are tipped with ochreous. Thoracic tergites beneath testaceous, outwardly margined with castaneous, abdominal sternites 1-6 with lateral ochreous spots. Coxae margined with testaceous.

Length $21 \mathrm{~mm}$. ; pronotum $7 \cdot 2 \mathrm{~mm} . \times 12 \mathrm{~mm}$.

Hab. "Australia” (British Mus., types ; Oxford Mus.).

7. C. picta, Tepp.

Platyzosteria (?) picta, Tepper, Tr. R. Soc. S. Australia, xviii, p. 182 (1894).

Known to me only from the description.

Queensland, Cooktown (Adelaide Mus., type).

Genus 8. Anamesia, Tepp.

Anamesia, Tepper, Tr. R. Soc. S. Australia, xvii, p. 69 (1893).

Pseudolampra, Tepper, t. c., p. 96 (1893). 
Characters. Ocelli present or absent. Pronotum with margins not reflexed nor incrassated. Tegminal rudiments absent. Dorsal surface of abdomen not scabrous, with shallow punctures. Posterior angles of none of the abdominal tergites produced, angles of 9th abdominal tergite often lobiform. Cerci short, flattened. Supra-

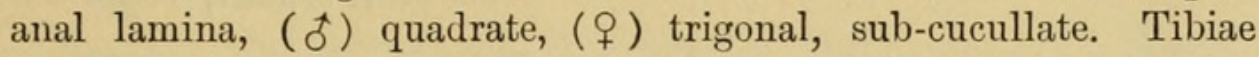
with spines on outer aspect tri-seriately arranged. Posterior metatarsus shorter than remaining joints, not spined beneath, its pulvillus occupying the greater part of the joint.

Type of the genus-A. frenchii, Tepp.

The foregoing description is drawn up after an examination of $A$. frenchii, Tepp., A. polyzona, Walk., a new form, and a larva of Pseudolampra punctata, Tepp. Mr. Froggatt at my request very kindly sent to $\mathrm{Mr}$. Tepper an example identified by me as $A$. frenchii, and Mr. Tepper, having compared the specimen with his own type, pronounces them to be identical. P. punctata, Tepp., and P. rothei, Tepp., are undoubtedly congeneric with frenchii and it is not easy to understand why the genus Pseudolampra was ever erected. The most important character of Anamesia is the obtuse angulation of the 7 th abdominal tergite; it is possible that all of the Tepperian species do not conform to this character, in which case they must be referred to other genera. The following key is quite provisional and too much reliance must not be placed on it.

\section{KEY TO THE SPECIES.}

1. Not unicolorous but banded or margined with paler colour.

2. Posterior margins of abdominal tergites ochreous.

3. Posterior margins of thoracic tergites ochreous . . . . . . . .

3'. Posterior margins of thoracic tergites not ochreous . . . . . . .

$2^{\prime}$. Posterior margins of abdominal tergites not ochreous.

3. Abdomen. bordered laterally with ochreous . . . . . . . .

3'. Abdomen not bordered laterally with ochreous . . . . . . . A. lindsayi, Tepp.

1'. More or less unicolorous.

2. Pronotum unicolorous testaceous

A. polyzona, Walk.

A. lambii, Tepp.

2'. Pronotum with fuscous maculae.

A. walkeri, sp. n. 
3. Rufo-castaneous beneath . . A. punctata, Tepp.

3'. Piceous beneath . . . . . A. rothei, Tepp.

Species of uncertain position...$\cdot\left\{\begin{array}{l}\text { A. circumcincta, Walk. } \\ \text { A. fulvornata, Tepp. } \\ \text { A. ornata, Tepp. }\end{array}\right.$

1. A. polyzona, Walk. (Pl. IX, figs. 34, 35.)

Polyzosteria polyzona, Walker, Cat. Blatt. Brit. Mus., p. 159 (1868).

Anamesia polyzona, Shelford, [in] Fauna Südwest Austral., ii, Lief. 9, Blattidae, Pl. XIII, f. 10 (1909).

f. Rufo-castaneous, nitid, impunctate, terminal tergites with shallow punctures and wrinkles. Head rufous, antennae testaceous, ocelli indistinct. Pronotum bordered all round with ochreous, meso- and metanotum and abdominal tergites 1-7 laterally and posteriorly bordered with ochreous. Angles of 9th abdominal tergite lobiform. Supra-anal lamina quadrate, castaneous at base, apex ochreous, margins entire, ape $x$ truncate, fimbriate, surpassed by the sub-genital lamina which is quadrate, produced, posteriorly not emarginate, with the styles lateral. Cerci short and flattened, exceeding the supra-anal but not the sub-genital lamina. Abdominal sternites posteriorly narrowly margined with flavotestaceous. Lę̧s flavo-testaceous, spines castaneous.

. Similar to of but head and legs rufo-castaneous, antennae rufescent. Angles of 9th abdominal tergite more lobiform. Supraanal lamina trigonal, margins serrate, not exceeded by the cerci.

Length (ô) $29 \mathrm{~mm}$., (q) $32 \mathrm{~mm}$. ; pronotum (ô) $8 \mathrm{~mm}$. $\times 14 \mathrm{~mm}$., (q) $10 \mathrm{~mm} . \times 18 \mathrm{~mm}$.

West Australia, Swan River (British Mus., type), Dirk Hartog, Evadu, Fremantle (Michaelsen and Hartmeyer), (Hamburg Mus.; Oxford Mus.).

2. A. lambii, Tepp.

Anamesia lambii, Tepper, Tr. R. Soc. S. Australia, xvii, p. 70 (1893).

Known to me only by the description.

Central Australia, Innaminka (Adelaide Mus., type).

3. A. frenchii, Tepp.

Anamesia frenchii, Tepper, t. c., p. 72 (1893).

The supra-anal lamina of the male is quadrate with truncate, non-emarginate, fimbriate apex, the lateral 
margins are minutely serrate; in the female the lamina is constructed as in polyzona + . The species varies in colour; in some examples the pale border is broad and the legs are testaceous, in others the pale border is narrow and the legs are castaneous.

North Queensland (Adelaide Mus., type); West Australia, Day Dawn (Michaelsen and Hartmeyer), (Hamburg Mus.), Lawlers (coll. Froggatt).

4. A. lindsayi, Tepp. Anamesia lindsayi, Tepper, t. c., p. 71 (1893).

Known to me only from the description.

West Australia, Fraser range (Adelaide Mus., type).

5. A. walkeri, sp. n.

f. Unicolorous testaceous. Head, dorsal surface and abdominal sternites finely punctate. Eyes very wide apart, equally distant with the antennal sockets. Supra-anal lamina quadrate, margins entire, apex truncate, non-emarginate, fimbriate, surpassed by the subgenital lamina which is quadrate, produced, posteriorly very slightly emarginate, with styles from near the base. Cerci short, blunt, exceeding both laminae.

Length $21 \cdot 2 \mathrm{~mm}$; pronotum $7 \cdot 1 \mathrm{~mm} . \times 11 \mathrm{~mm}$.

New S. Wales, Sydney (Oxford Mus., type).

This is a somewhat remarkable species, superficially resembling very closely Zonioploca pallida mihi, but distinguished by the non-incrassated margins of the pronotum, non-produced angles of the abdominal tergites, absence of granules on the dorsal surface and by the unicolorous legs. The distance of the eyes apart shows that much reliance cannot be placed on this character for purposes of discriminating between Old and New World Blattinae. I have much pleasure in naming this interesting species after my friend and colleague, Commander J. J. Walker, R.N., who presented the unique example to the Oxford Museum.

6. A. punctata, Tepp.

Pseudolampra punctata, Tepper, Tr. R. Soc. S. Australia, xvii, p. 97 (1893).

West Australia, Fraser range (Adelaide Mus., type); South Australia, Tennant's Creek (Deutsche Ent. Nat. Mus.). 
7. A. rothei, Tepp.

Pseudolampra rothei, Tepper, t. c., p. 98 (1393).

South Australia, Sedan (Adelaide Mus., type).

8. ? A. ornata, Tepp.

Pseudolampra ornata, Tepper, t. c., p. 98 (1893).

South Australia (Adelaide Mus., type).

9. ? A. circumcincta, Walk.

Polyzosteria circumcincta, Walker, Cat. Derm. Salt. Brit. Mus. V. Suppl. Blatt., p. 36 (1871).

A young larva, possibly of $A$. frenchii.

Australia (British Mus., type).

10. ? A. fulvornata, Tepp.

Anamesia (?) fulvornata, Tepper, Tr. R. Soc. S. Australia, x viii, p. 177 (1894).

$\mathrm{Mr}$. Tepper himself is doubtful of the systematic position of this species.

Victoria, Howbulan (Adelaide Mus., type).

\section{Genus 9. Desmozosteria, Shelf.}

Desmozosteria, Shelford, [in] Fauna Südwest Austral., ii, Lief. 9, Blattidae, p. 139 (1909).

Characters. Allied to Zonioploca, but the angles of none of the abdominal tergites backwardly produced. Lateral margins of the pronotum incrassated. Tegminal rudiments absent. Dorsal surface punctate or smooth. Supra-anal lamina ( $\hat{\text { ) }}$ quadrate, margins entire, (q) trigonal, cucullate. Cerci short, flattened. Posterior metatarsus very short, not spined beneath.

Type of the genus D. michaelseni, Shelf.

The genus stands in the same relation to Zonioploca that Anamesia does to Cosmozosteria.

\section{KEY TO THE SPECIES.}

1. Thoracic tergites uniformly punctate . Dr. grosse-punctata, sp. n.

1 '. Thoracic tergites not uniformly punctate, or smooth.

2. Thoracic tergites smooth . . . D. michaelseni, Shelf.

2 '. Thoracic tergites laterally finely punctate.

3. Castaneous banded with ochreous . D. cincta, sp. n.

3'. Rufescent . . . . D. rufescens, Shelf. 
1. D. grosse-punctata, sp. n.

ๆ. Above piceous; lateral and posterior margins of all the tergites, anterior margin of pronotum, bright ochreous. Thoracic tergites deeply and closely punctate, abdominal tergites smooth. Beneath uniformly flavo-testaceous. Vertex, antennae except the basal joints, maxillary palpi, upper border of femora, the tibiae and tarsi, piceous. Anterior and lateral margins of pronotum, lateral margins of meso- and metanotum strongly incrassated, the posterior angles strongly produced backwards. Supra-anal lamina faintly scabrous, trigonal, margins entire, apex not emarginate, not exceeded by the cerci which are ochreous above and castaneous below.

Length $23.5 \mathrm{~mm}$; pronotum $7.3 \mathrm{~mm}$. $\times 10^{\cdot 1} \mathrm{~mm}$.

Habitat unknown (Oxford Mus., type).

A very distinct species, undoubtedly Australian in origin.

2. D. michaelseni, Shelf.

Desmozosteria michaelseni, Shelford, op. cit., p. 139, Pl. XIII, fig. 9 (1909).

West Australia, Boorabbin (Michaelsen and Hartmeyer), (Hamburg Mus., type).

3. D. cincta, sp. n.

q. Above nitid, castaneous, posterior margins of all the tergites and the lateral margins of the thoracic tergites ochreous; beneath sordid testaceous. Occiput and vertex of head castaneous ; antennae with basal joint castaneous, remainder piceous, maxillary palpi piceous. Lateral margins of thoracic tergites strongly incrassated, discs finely punctate, posterior margins convex. Supra-anal lamina sub-quadrate, angles rounded, non-emarginate, barely exceeded by the cerci which are testaceous. Femora and tibiae rufo-castaneous on the dorsal aspect, testaceous on the ventral aspect.

Length $26.6 \mathrm{~mm}$; pronotum $8.4 \mathrm{~mm}$. $\times 12 \mathrm{~mm}$.

Central Australia ( $v$. Leonhardi), (Senckenberg Mus., type).

Superficially the insect closely resembles Anamesia polyzona, Walk.

4. D. rufescens, Shelf.

Desmozosteria rufescens, Shelford, op. cit., p. 140 (1909).

West Australia, Denham (Michaelsen and Hartmeyer), (Hamburg Mus., type; Oxford Mus.). 
Genus 10. Temnelytra, Tepp.

Temnelytra, Tepper, Tr. R. Soc. S. Australia, xvii, p. 38 (1893).

Characters. Body flattened and depressed. Antennae longer than the body. Pronotum anteriorly parabolic, posteriorly truncate, exposing the large scutellum. Tegmina quadrate or sub-quadrate, extending to the 1st abdominal tergite. Wings entirely absent. 1st abdominal tergite $(\hat{\delta})$ with scent-gland opening. Posterior angles of distal abdominal tergites produced ( $T$. undulivitta, Walk., $\delta$ is an exception). Supra-anal lamina, ( $\delta$ ) quadrate, margins entire, ( $q$ ) triangular, apex emarginate. Cerci longer than the lamina in both sexes. Posterior metatarsus very short, spined beneath.

Type of the genus-T. truncata, Br.

This is a well-defined genus. The obtuse angles of the distal abdominal tergites in T. undulivitta, Walk. (§) , is paralleled in the genus Cutilia by $C$. sedilloti, Bol. (र̂े), also a New Zealand species. The species abbreviata included by Mr. Tepper in this genus is a true species of Temnopteryx (sub. fam. Phyllodromiinae); I have seen the type, which is in the Melbourne Museum.

\section{KEY TO THE SPECIES.}

1. Pronotum with fuscous vittæ . . . T. undulivitta, Walk.

1'. Pronotum without fuscous vittæ.

2. Tegmina quadrate . . . . T. truncata, Br.

2'. Tegmina with outer angles hebetate T. subtruncata, Tepp.

1. T. undulivitta, Walk. (Pl. IX, fig. 36.)

Periplaneta undulivitta, Walker, Cat. Blatt. Brit. Mus., p. 144 (1868).

đ. Rufo-testaceous. A band between the eyes and two stripes down the face, castaneous. Antennae rufo-testaceous. Pronotum with the disc rather darker than the margins, an undulate castaneous vitta on each side, extending on to the tegmina, which are quadrate, their venation obsolete. Abdomen fusco-castaneous, margins and two spots on each side rufo-testaceous. Posterior angles of abdominal tergite not backwardly produced. Supra-anal lamina quadrate, posterior angles acute, posteriorly widely emarginate. Cerci very short and blunt. Sub-genital lamina quadrate, styles as long as cerci, lateral. Legs testaceous.

ๆ. Similar, abdomen above testaceous with lateral castaneous spots 
on tergites 2-5, tergites 6 and 7 castaneous. Supra-anal lamina triangular, apex emarginate, castaneous at base, rest testaceous. Posterior angles of abdominal tergites backwardly produced. Cerci longer and more acuminate.

Length (ơ) $15 \mathrm{~mm}$., ( q ) $14 \mathrm{~mm}$. ; tegmina, (ơ) $4 \mathrm{~mm} .$, (q) 3.5 $\mathrm{mm}$.; pronotum $5 \mathrm{~mm}$. $\times 6 \mathrm{~mm}$.

New Zealand (British Mus., type; Vienna Mus.).

2. T. truncata, Br. (Pl. IX, figs. $37 a$ and $37 b$.

Polyzosteria truncata, Brunner von Wattenwyl, Nouv. Syst. Blatt., p. 217 (1865).

Temnelytra harpuri, Tepper, Tr. R. Soc. S. Australia, xvii, p. 39 (1893).

I have seen specimens in the Melbourne Museum identified by Mr. Tepper, and there can be no doubt of the specific identity of truncata and harpuri.

New South Wales (Vienna Mus., type of truncata), Goulburn Range (Melbourne Mus.); Victoria, Gippsland (Melbourne Mus.; Oxford Mus.); South Australia, Kangaroo Is. (Adelaide Mus., type of harpuri).

3. T. subtruncata, Tepp.

Temnelytra subtruncata, Tepper, op. cit., xix, p. 164 (1895).

Distinguished by the darker colour and by the form of the tegmina, which are shorter in the $q$ than in the $\hat{\delta}$, scarcely extending beyond the middle of the metanotum.

Victoria, Fernshaw (Melbourne Mus., types; Oxford Mus.).

\section{Genus 11. Scabina, nov.}

Characters. Eyes and antennal sockets equally far apart. Ocelli present. Antennae robust. Pronotum parabolic, posteriorly truncate, exposing the scutellum. Tegmina quadrate, corneous, not extending beyond the 1st abdominal tergite. Wings rudimentary, squamiform. Posterior angles of abdominal tergites strongly produced backwards. Supra-anal lamina ( $\delta$ ) quadrate, entire. Cerci exceeding the lamina. Styles long, slender. Posterior metatarsus shorter than succeeding joint, not spined beneath, its pulvillus apical.

Type of the genus-S. antipoda, Kirby.

The genus is very close to Eurycotis and Pelmatosilpha of TRANS. ENT. SOC. LOND. 1909.-PART II. (MAY) X 
the New World, but all the species of those genera that I have been able to examine have the posterior metatarsus spined beneath.

1. S. antipoda, Kirby.

Pelmatosilpha (?) antipoda, Kirby, Ann. Mag. Nat. Hist., ser. 7, xii, p. 376 (1903).

To Kirby's description may be added :-

Tegmina with outer margins incrassate and sinuate. Wings squamiform, scarcely exceeding the metanotum. Supra-anal lamina with non-serrate margins, apex non-emarginate. Styles not lateral in position.

Length $25 \mathrm{~mm}$. ; tegmina $7.5 \mathrm{~mm}$. ; pronotum $8.9 \mathrm{~mm} . \times 12 \mathrm{~mm}$.

Queensland (British Mus., type; Oxford Mus., co-type).

\section{Genus 12. Methana, Stål.}

Methana, Stål, Oefv. Vet. Akad. Förh. xxxiv (10), p. 36 (1877).

Wodongia, Tepper, Tr. R. Soc. S. Australia, xix, p. 155 (1895).

Characters. Antennae longer than body. Pronotum anteriorly parabolic, almost covering vertex of head, posteriorly very obtusely angled. Scutellum not exposed. Tegmina and wings fully developed, at least as long as the abdomen, generally longer. Supraanal lamina ( $\delta$ ) quadrate, margins not serrate, $(q)$ triangular, apex emarginate. Cerci long, acuminate. Femora heavily spined. Posterior metatarsus about equal in length to remaining joints, biseriately spined beneath, its pulvillus apical ; remaining joints of tarsus with large pulvilli, not spined beneath.

Type of the genus: $M$. marginalis, Sauss.

\section{KEY TO THE SPECIES.}

1. Uniform castaneous.

2. Large species, exceeding $30 \mathrm{~mm}$. in total length . . . . . . . . .

2'. Smaller species, less than $30 \mathrm{~mm}$. in total length . . . . . . . . M. convexa, Walk.

1'. Not uniform castaneous.

2. Pronotum testaceous with fuscous vittae.

2 '. Pronotum castaneous with flavo-testa-

M. curvigera, Walk. ceous margins. 
3. Posterior margin of pronotum not bordered with flavo-testaceous.

4. Disc of pronotum immaculate . . M. marginalis, Sauss.

4'. Disc of pronotum with two ochreous maculae . . . . . . . M. soror, Sauss.

$3^{\prime}$. Posterior margin of pronotum bordered with flavo-testaceous.

4. Tegmina laterally margined with flavo-testaceous . . . . . $M$. papua, Shelf.

4'. Tegmina uniform castaneous . . M. hosei, sp. n.

Species of doubtful position . . . . . M. pallipalpis, Serv.

\section{M. magna, sp. n.}

o and $q$. Castaneous, nitid. Head sordid testaceous, vertex, a band between the antennal sockets, a W-shaped band at base of clypeus, castaneous. Antennae with basal joint testaceous, remainder castaneous. Pronotum with sides deflexed, posteriorly truncate. Tegmina and wings exceeding apex of abdomen. Supra-anal lamina (ઠ) quadrate, fimbriate, margins entire, ( $q$ ) triangular, apex widely emarginate. Cerci very long, acuminate. Genital styles ( $\delta$ ) very long and slender. Coxae and front legs testaceous, mid femora rufotestaceous with castaneous lines, mid-tibiae and tarsi and hind legs castaneous. Posterior metatarsus a trifle shorter than remaining joints, its pulvillus large.

f and $q$. Total length $40-41 \mathrm{~mm}$. ; length of body, 34-35 mm. ; of tegmina, 30-31 mm.; pronotum 10.5 mm. $\times 15 \mathrm{~mm}$.

Bonneo, Sarawak (Shelford) (Oxford Mus., ô and + types).

The species bears a close superficial resemblance to Periplaneta valida, Br., the type of which I have seen, but can readily be distinguished by the structure of the tarsi.

\section{M. convexa, Walk.}

Periplaneta convexa, Walker, Cat. Derm. Salt. Brit. Mus., Suppl. Blatt., p. 152 (1869).

Methana rufescens, Kirby, Ann. Mag. Nat. Hist., ser. 7, xii, p. 374 (1903).

๙. Rufo-castaneous, nitid. Head rufo-castaneous or piceous; mouth-parts testaceous. Tegmina and wings not extending much beyond the apex of the abdomen. Supra-anal lamina produced, quadrate, margins entire, apex not emarginate. Sub-genital lamina 
trapezoidai, styles very long and slender. Cerci long and acuminate. Legs rufo-castaneous.

Total length 23-24:5 mm.; length of body 19-21 mm. ; length of tegmina, $165.19 \mathrm{~mm}$. ; pronotum $7 \mathrm{~mm}$. $\times 9 \mathrm{~mm}$.

QueEnsland, Moreton Bay (British Mus., type of convexa); New South Wales, Sydney, Home Bush $(W . W$. Froggatt), (British Mus., type of rufescens; Oxford Mus.).

I have compared the types and found them identical. Kirby gives the species identified by Brunner as pallipalpis, Serv., as a synonym of rufescens, but in Brunner's species the supra-anal lamina ( $\hat{\delta}$ ) is described as "profondément découpée," whereas in rufescens this is not the case; this is too important a character to be ignored.

3. M. curvigera, Walk.

Periplaneta curvigera, Walker, Cat. Blatt. Brit. Mus., p. 134 (1868).

Queensland, Moreton Bay (British Mus., type).

4. M. marginalis, Sauss.

Periplaneta marginalis, Saussure, Rev. Zool. (2), xvi, p. 319 (1864).

Periplaneta ligata, Brunner von Wattenwyl, Nouv. Syst. Blatt., p. 234 (1865).

"Australia" (Paris Mus., type of marginalis); QueensLand, Port Curtis (Vienna Mus., type of ligata); New South Wales, Hunter River (Oxford Mus.).

5. M. soror, Sauss.

Periplaneta soror, Saussure, Rev. Zool. (2), xvi, p. 319 (1864),

Periplaneta biquadrata, Walker, Cat. Blatt. Brit. Mus., p. 134 (1868).

Periplaneta oculata, Walker, Cat. Derm. Salt. Brit. Mus., Suppl. Blatt., p. 152 (1869).

Wodongia lunata, Tepper, Tr. R. Soc. S. Australia, xix, p. 155 (1895).

This differs from the preceding species by the greater distance apart of the eyes, the immaculate head and the pale legs. The colouring of the pronotum varies a good 
deal, sometimes the two maculae on the disc becoming confluent as in lunata.

"Australia" (Paris Mus., type of soror ; British Mus., type of biquadrata; Oxford Mus., type of oculata); VICTORIA, Wodonga (Melbourne Mus., type of lunata).

6. M. papua, Shelf.

Methana papua, Shelford, Mém. Soc. ent. Belg., xv, p. 234 (1908).

British New Guinea, Astrolabe District (Genoa Mus., of type; Brussels Mus., $q$ type).

\section{M. hosei, sp. n.}

q. Head, body and legs piceous, front coxae and a large blotch on the posterior coxae testaceous. Pronotum sub-quadrate, sides strongly deflexed, bordered all round with ochreous, the border being very broad on the postero-lateral and posterior margins, its inner margin sinuate. Tegmina and wings uniform castaneous, extending considerably beyond the apex of the abdomen. Supra-anal lamina triangular, cucullate, apex triangularly emarginate. Cerci moderate.

Total length $29 \mathrm{~mm}$. ; length of body $24 \mathrm{~mm}$; l length of tegmina $23 \mathrm{~mm}$. ; pronotum $7.9 \mathrm{~mm} . \times 9 \mathrm{~mm}$.

Bonneo, Sarawak, Baram District (C. Hose), (Oxford Mus., type).

8. ? M. pallipalpis, Serv.

Kakerlac pallipalpis, Serville, Hist. Nat. Ins. Orth., p. 71 (1839).

? Periplaneta pallipalpis, Brunner von Wattenwyl, Nouv. Syst. Blatt., p. 238 (1865).

As the type of this species is lost, its systematic position is quite uncertain. Brunner states (Ann. Mus. Civ. Genova, ser. 2a xiii, p. 36 (1893) that the species as identified by him belongs to the genus Methana.

Java; Sumatra (de Haan); Australia (Brunner).

Genus 13. Paramethana, Shelf.

Paramethana, Shelford, Sjöstedt's Kilimandjaro-Meru Exp., Blattodea, p. 31 (1907).

Characters.-Differs from Methana in the short tegmina and wings which do not extend beyond the fifth abdominal tergite and 
in the discoidal pronotum. Third antennal joint nearly three times longer than the second.

Type of the genus-P. robusta, Shelf.

$P$. robusta, Shelf.

Paramethana robusta, Shelford, l. c., p. 31, Pl. II, fig. 7 (1907).

German East Africa, Lower Meru (Stockholm Mus., type; Oxford Mus.).

XI. Revision of THE GENus fryna, BR., wiTH A DESCRIPTION OF A NEW GENUS.

The genus Gyna was formed in 1865 (Brunner, Nouv. Syst. Blatt., p. 266) for the reception of some species of African Blattidae that previously had been placed in Panchlora; since that date a number of species have been added by various authors, and as many of the species are closely allied, cryptically coloured forms, presenting few salient features of taxonomic importance, their identification has been attended with considerable difficulty. Fortunately I have been able to examine and compare nearly all the types, and my grateful thanks are due to Dr. H. Dohrn of Stettin, Dr. Y. Sjöstedt of Stockholm, Dr. F. Römer of Frankfort-à-M., Dr. K. Holdhaus of Vienna, Dr. Giglio-Tos of Cagliari and Dr. M. Bedot of Geneva for the loan of the valuable specimens in their charge; without this friendly co-operation a satisfactory revision of the genus was out of the question. I have received for determination large collections of African Blattidae from various continental Museums, and as allbut especially the West African collections-are very rich in examples of this particular genus I am confident that I have in my possession at present a greater amount of material for the revision of the genus than has ever before been gathered together. The tropics of West Africa may be regarded as the head-quarters of the genus, for no less than 18 out of the 23 known species occur there; there are 4 East African and only 2 South African species. In my account of the Blattidae collected by Dr. Y. Sjöstedt on his Kilimandjaro-Meru expedition I gave my reasons for believing that the genera Trichomera, Kirby, and Apotrogia, Kirby, were based on larval forms of Gyna and I still see no reason to modify that 
opinion. The West-African collections before me contain quantities of examples that could be referred equally well to either of Mr. Kirby's genera but I have never yet seen an adult example that could be referred to them. The erect pubescence of Trichomera insignata persists in many species of Gyna, and the structural differences between Trichomera and Apotrogia on the one hand and Gyna on the other are such as we are thoroughly familiar with in the larvae and adults of other genera of Blattidae.

The species of Gyna can be divided into two sections; in one section the pronotum is smooth and nitid, rich castaneous in colour, with ochreous margins; in the other section the pronotum is testaceous but the disc is occupied with a piceous or castaneous lyrate marking that under the lens presents an appearance as if it had been chiselled out of the surface of the pronotum; the form and extent of the marking is very variable and presents few characters of importance in classifying the species. G. hyalina may be regarded as intermediate in character between the two sections of the genus and $G$. capucina in its pronotal colour and sculpture occupies an isolated position. The distance apart of the eyes on the vertex in the male is a character of some importance and full use has been made of it in the following synoptical key. Another character that can be employed, though with caution, to separate species with lyrate markings on the pronotum, is the presence or absence of a circular rufescent macula on the discoidal field of the tegmina. The posterior part of the pronotum and the tegmina in some species (e. g. G. maculipennis and G. fervida) present a peculiar mottled appearance, which is due to the irregular deposition of opaque testaceous pigment between the two layers of chitin, the chitin itself being quite transparent. De Bormans (Ann. Soc. ent. Belg., xxv, p. 21, 1881) figures the ootheca of $G$. caffrorum; from his figure and description I believe that the ootheca is merely a membranous sac and that the species of this genus are viviparous or ovo-viviparous like the Epilamprinae whose place in Africa is so largely taken by the species of Gyna. Karny (Jenaische Denkschriften, xiii, p. 382, 1908) has suggested that the ulnar rami of the wings in a species described by him as Gyna stridulans have the power of producing a rattling noise when the insect flies. He sees a resemblance between this part of the wing in the cock- 
roach and the anterior field of the wings of certain Acridiidae and Locustidae which he has proved to produce a rattling noise during flight with the wings alone, neither the legs nor the tegmina taking any part in the operation (Stett. Ent. Zeit. 1908, pp. 112-119). This rattling or rustling noise is of course to be distinguished from the true stridulation produced by insects at rest. The wingstructure of Gyna stridulans (=caffrorum, Stal) is by no means exceptional, for not only have the other species of the genus a similar wing-venation but other genera present similar features; it would be interesting to learn from observations in the field if any Blattidae produce a rattling noise when flying.

\section{Genus Grna, Br.}

Gyna, Brunner von Wattenwyl, Nouv. Syst. Blatt., p. 266 (1865).

Trichomera, Kirby, Ann. Mag. Nat. Hist., ser. 6, xviii p. 257 (1896).

Apctrogia, Kirby, op. cit., ser. 7, v, p. 281 (1900).

\section{KEY TO THE SPECIES.}

1. Pronotum with anterior half castaneous, posterior half ochreous .

$1^{\prime}$. Pronotum not as above.

2. Pronotum with disc castaneous, margins flavo-testaceous or ochreous.

3. Tegmina flavo-marginate throughout the greater part of their length.

4. Eyes (o) touching or nearly touching on vertex of head.

5. Larger (19-20 $\mathrm{mm}$. in total length) . . . .

5'. Smaller (15 mm. in total length). . . . .

$4^{\prime}$. Eyes (ô) wide apart . . . G. scutelligera, Walk.

G. costalis, Walk.

G. castanea, sp. n.

3'. Tegmina not flavo-marginate throughout the greater part of their length.

4. Tegmina castaneous with 4 ochreous maculae. . . G. gloriosa, Stål. 
4'. Tegmina with basal two-
fifths castaneous, re-
mainder testaceous. .

2'. Pronotum testaceous or flavo-

G. jocosa, Shelf. testaceous with lyrate chiselled markings on the disc.

3. Lyrate markings on dise of pronotum obsolescent.

(Bright flavous species) . . G. laticosta, Walk.

3'. Lyrate markings on disc of pronotum not obsolescent.

4. Small species (not exceeding $22 \mathrm{~mm}$.).

5. Eyes nearly touching on vertex of head . . .

5 '. Eyes not nearly touching

G. oblonga, Borg. on vertex of head.

6. Frons strongly striate.

6 . Frons not strongly striate. . . . G. peringueyi, sp. n.

4'. Larger species.

G. nigrifrons, Bol.

5. Antennae bifasciated with ochreous.

6. Mediastinal field of tegmina opaque testaceous . . . .

6'. Mediastinal field concolorous with rest of

tegmina . . . . G. sculpturata, sp. n.

5'. Antennae not bifasciated

G. centurio, Dohrn. with ochreous.

6. Eyes touching or nearly touching on vertex of head.

7. Tegmina with rufes cent macula in centre of disc.

8. Antennae rufofuscous or fuscous

8'. Antennae piceous, nitid.

9. Distance apart of eyes on vertex 
of head greater than thickness of 1st antennal joint.

10. Larger species (30 $\mathrm{mm}$. in length). . G. maculipennis, Schaum.

10'. S malle r species (22$24 \mathrm{~mm}$. in length).

9'. Distance apart G. kazungulana, Gig.-Tos. of eyes on vertex of head less than thickness of 1st antennal joint .

7'. Tegmina immaculate. G. lurida, Sauss.

G. incommoda, sp. n. $6{ }^{\prime}$. Eyes wide apart on vertex of head.

7. Smaller species (20 $\mathrm{mm}$. in length). .

8. Tegmina with rufescent macula on dise . . . . . 8'. Tegmina without rufescent macula on disc . . . G. aestuans, Sauss.

7'. Larger species (30 $\mathrm{mm}$. in length).

8. Tegmina with rufescent macula on disc . . . . . 8'. Tegmina without G. fervida, Sauss. rufescent macula on disc . . . . q

6. Eyes close together on vertex of head. . .

6'. Eyes wide apart on vertex of head.

7. Tegmina without rufescent macula on disc.

8. Lyrate markings of pronotum not fused . . . G. incommoda, sp. n. 
8'. Lyrate markings of pronotum fused . G. aurivillii, Borg.

7. Tegmina with rufescent macula on disc.

8. Supra-anal lamina short, rounded. 8'. Supra-anal lamina produced, subquadrate, subbilobate.

9. Antennæ rufofuscous or fuscous. Distance apart of eyes equals length of 1st antennal joint.

10. Rufescent macula on disc of tegmina large. 10'. Rufescent macula on disc of tegmina small, occasionally absent . .

9'. Antennae piceous, G. aetola, sp. n.
G. lurida, Sauss.
G. fervida, Sauss. nitid. Distance apart of eyes greater than length of 1 st antennal joint.

10. Anterior part of wings heavily suffused with a dark castaneous . . G. caffrorum, Stål.

10'. Anterior part of wings not as above . G. maculipennis, Schaum

Doubtful species . . . . . . . G. colini, Rochebr. 
1. G. capucina, Gerst.

Gyna capucina, Gerstaecker, Mitt. Ver. Neuvorpomm. u. Rugen, xiv, p. 72 (1883).

Gyna maculipennis, Brunner von Wattenwyl, Nouv. Syst. Blatt., p. 268, Pl. VI, fig. 30 (1865).

A common and well-marked species that occurs in most collections from West Africa. There is a variety with the pronotum anteriorly margined with ochreous.

Kamerun (Greifswald Mus., type; Oxford Mus.; Berlin Mus. ; Vienna Mus.) ; Fernando Po (Genoa Mus.); French Congo (Genoa Mus.).

2. G. scutelligera, Walk.

Panchlora scutelliger'a, Walker, Cat. Blatt. Brit. Mus., p. 32 (1868).

f. Head testaceous with frons castaneous; antennae fuscous. Eyes almost touching on vertex. Pronotum with the dise castaneous, broadly margined all round with flavo-testaceous. Tegmina castaneous, outwardly margined almost to apex with flavo-testaceous. Wings suffused with rufo-castaneous, ulnar vein with $10 \mathrm{rami}, 7$ being incomplete. Abdomen rufo-testaceous, supra-anal lamina sub-quadrate, apex not emarginate, exceeded by the sub-genital lamina which is small and furnished with 2 styles. Cerci moderate. Legs rufo-testaceous.

Total length $19.5 \mathrm{~mm}$; length of body $15 \mathrm{~mm}$; length of tegmina $17 \mathrm{~mm}$; pronotum $6.3 \mathrm{~mm} . \times 7.5 \mathrm{~mm}$.

Gambia (British Mus., type); Pontuguese Guinea, Bolama (L. Fea), (Genoa Mus.).

3. G. costalis, Walk.

Panchlora costalis, Walker, Cat. Blatt. Brit. Mus., p. 35 (1868).

f. Eyes nearly touching on vertex of head. Head rufo-testaceous; antennae testaceous at base, remainder fuscous. Pronotum margined broadly all round with testaceous, disc castaneous at base, apex hyaline, outer margin testaceo-hyaline. Wings hyaline, costal margin faintly suffused with ochreous, ulnar vein with 10 rami, 7 of which are incomplete. Abdomen and legs flavo-testaceous. Supraanal lamina sub-quadrate, not surpassing the sub-genital lamina, which is small and slightly asymmetrical.

Total length $15 \mathrm{~mm}$.; length of body $13 \mathrm{~mm}$.; length of tegmina $12 \mathrm{~mm}$.; pronotum $4 \mathrm{~mm} . \times 6 \mathrm{~mm}$. 

Mus.).

"West AfricA" (British Mus., type); Togo (Berlin

The species is to be distinguished by the broad testaceous margin running all round the pronotum and by the apical three-fifths of the tegmina being hyaline, the castaneous colouring of the tegmina occupies the basal two-fifths, and is produced along the marginal field towards the apex.

\section{G. castanea, sp. n.}

o. Differs from scutelligera and costalis by the greater distance apart of the eyes on the vertex of the head. Head rufo-testaceous, vertex between the eyes, which are nearly $1 \mathrm{~mm}$. apart, castaneous. Pronotum with disc castaneous, margins broadly flavo-testaceous, at the postero-lateral angles the castaneous almost reaches the outer border of the pronotum. Tegmina dark castaneous, flavo-marginate almost to their apex. Wings suffused with castaneous. Abdomen and legs as in the preceding species.

Total length, $16 \mathrm{~mm}$.; length of body $14.8 \mathrm{~mm}$.; length of tegmina $14 \mathrm{~mm}$.; pronotum $5 \mathrm{~mm}$. $\times 6 \mathrm{~mm}$.

Togo, Bismarckburg (L. Conradt), (Berlin Mus.).

5. G. gloriosa, Stål.

Blatta gloriosa, Stål, Oefv. Vet.-Akad. Förh., xii, p. 351 (1856).

Panchlora africana, Saussure, Rev. Zool. (2), xvi, p. 342 (1864).

Gyna africana, Saussure, Mém. Soc. Sci. Phys. Nat. Genève, xx, p. 275 (1869).

Gyna pomposa, Brunner von Wattenwyl, Nouv. Syst. Blatt., p. 269 (1865).

A common species ranging from Sierra Leone to the Congo.

6. G. jocosa, Shelf.

Gyna jocosa, Shelford, Mém. Soc. ent. Belg., xv, p. 234 (1908).

Congo Free State (Brussels Mus., type; British Mus.).

7. G. laticosta, Walk.

Panchlora laticosta, Walker, Cat. Blatt. Brit. Mus., p. 33 (1868). 
Gyna buchholzi, Gerstaecker, Mitt. Ver. Neuvorpomm u. Rügen, xiv, p. 72 (1883).

? A potrogia angolensis, Kirby, Ann. Mag. Nat. Hist., ser. 7, v, p. 281 (1900); Distant's Ins. Transvaal, p. 21, Pl. I, fig. 11 (1900).

A handsome species, readily distinguished by the obsolescent markings on the pronotum and by its primroseyellow colour.

Kamerun (Greifswald Mus., type of buchholzi; Oxford Mus.; Berlin Mus.; coll. Bolivar); Fernando Po (Greifswald Mus.); Angola (British Mus., type of laticosta).

8. G. oblonga, Borg.

Gyna oblonga, Borg, Bih. Svensk. Vet.-Akad. Handl., xxviii, Afd. 4, No. 10, p. 21, Pl. II, fig. 1 (1902).

The form and extent of the markings on the pronotum varies considerably; a reliable character is presented by the oblique fascia at the apex of the tegmina, which is present in all the specimens of both sexes that I have seen.

Kamerun (Stockholm Mus., type; Oxford Mus.; Berlin Mus.; coll. Bolivar).

9. G. nigrifrons, Bol.

Gyna nigrifrons, Bolivar, J. Sci. Lisboa (2) i, p. 77 (1889).

Benguella (Lisbon Mus., type); Loanda (coll. Bolivar).

10. G. peringueyi, sp. n.

f. Testaceous. Eyes on vertex $1 \mathrm{~mm}$. apart. Vertex and frons not striate. Four stripes on the vertex, the vertex between the eyes, a macula between the antennal sockets, two spots on the clypeus, castaneous; antennae castaneous at base, remainder fuscous. Pronotum faintly striate posteriorly, lyrate markings clearly defined. Tegmina mottled with testaceous, no rufescent macula on disc, a piceous spot between radial and mediastinal veins. Wings slightly infuscated, ulnar vein with $11 \mathrm{rami}, 7$ being incomplete. Abdomen testaceous mottled with castaneous; supra-anal and sub-genital laminae of usual shape. Legs pale testaceous, posterior metatarsi elongate.

Total length $20 \mathrm{~mm}$, ; length of body $17 \mathrm{~mm}$. ; length of tegmina $18 \mathrm{~mm}$.; pronotum $5 \cdot 1 \mathrm{~mm} . \times 6 \cdot 8 \mathrm{~mm}$.

Benguella (Cape Town Mus., type). 
11. G. centurio, Dohrn.

Gyna centurio, Dohrn, Stettin Ent. Zeit., xlix, p. 129 (1888).

A very distinct species on account of the opaque testaceous or flavous macula in the mediastinal field of the tegmina.

Kamerun (Stettin Mus., type; Oxford Mus.).

\section{G. sculpturata, sp. n.}

f. Testaceous, the pigment evenly distributed. Eyes almost touching on vertex ; a castaneous band between the ocelli. Antennae piceous, 4-6 joints beyond the middle and 4 joints immediately before the apex ochreous. Pronotum more strongly produced posteriorly than usual, the process transversely striate, its apex and border very narrowly piceous, disc with the usual lyrate marking. Tegmina rather narrow, with variable piceous mottlings in the anal field and at the apex, usually a piceous macula in the middle of the dise, a line along the mediastinal vein at base and the anal vein piceous, mediastinal area and costal margin beneath castaneous. Wings hyaline, with the marginal field flavid, becoming castaneous at apex, ulnar vein with $12 \mathrm{rami}, 7$ being incomplete. Abdomen above and beneath and the legs flavo-testaceous. Supra-anal lamina sub-bilobate, considerably exceeding the sub-genital lamina which is small and asymmetrical, styles slender. Cerci small, 11-jointed.

․ Similar, but much larger. Tegmina unicolorous, abdomen beneath and legs rufo-castaneous. Distance of eyes apart rather less than length of 1st antennal joint. Supra-anal lamina bilobed, exceeding the sub-genital lamina which is ample, produced, with sinuate margins.

f. Total length $26 \mathrm{~mm}$; length of body $19 \mathrm{~mm}$. ; length of tegmina $19 \mathrm{~mm}$.; pronotum $6 \cdot 2 \mathrm{~mm} . \times 7 \cdot 6 \mathrm{~mm}$.

q. Total length $39 \mathrm{~mm}$.; length of body $33 \mathrm{~mm}$.; length of tegmina $33 \mathrm{~mm}$.; pronotum $12 \mathrm{~mm} . \times 13 \mathrm{~mm}$.

Kamerun (Berlin Mus., ô type; Deutsches Entom. Nat. Mus.; coll. Bolivar); Benin (Oxford Mus., + type); Togo (Berlin Mus.).

\section{G. aetola, sp. n.}

o. Eyes touching on vertex of head. Frons castaneous and concave, vertex striate ; antennae castaneous at base, remainder fuscous. Pronotum striate posteriorly and anteriorly, with the usual lyrate marking on disc. Tegmina rufo-testaceous, mottled, a piceous spot 
between the mediastinal and radial veins, a rufescent macula on the disc. Wings with marginal field flavous, ulnar vein with 11 rami, 7 being incomplete. Abdomen rufo-testaceous; supra-anal lamina sub-quadrate, apex distinctly emarginate, sub-genital lamina of usual shape. Legs concolorous with abdomen, posterior metatarsi moderately elongate.

q. Differs only in the greater distance apart of the eyes, larger size, sub-bilobate supra-anal lamina and ample, semi-orbicular subgenital lamina.

f. Total length $25-26 \mathrm{~mm}$. ; length of body $20-22 \mathrm{~mm}$. ; length of tegmina 19-22 mm.; pronotum $6 \cdot 1 \mathrm{~mm} . \times 8 \mathrm{~mm}$.

q. Total length $30 \mathrm{~mm}$; length of body $28 \mathrm{~mm}$. ; length of tegmina $25.5 \mathrm{~mm}$; pronotum $10 \mathrm{~mm} . \times 11.8 \mathrm{~mm}$.

French Guinea, Kouroussa (Oxford Mus., $\hat{\jmath}$ type ; Paris Mus.); Portuguese Guines, Bolama (L. Fea), (Genoa Mus.), o type.

This is a species that hitherto I have referred to $G$. aestuans, Sauss., but on examining the type of that species I find that it is different from the French and Portuguese Guinea examples here described.

\section{G. maculipennis, Schaum.}

Panchlora maculipennis, Schaum, Ber. Akad. Berlin, 1853, p. 776 ; Peters, Reise Mossamb., Zool. v, p. 109, Pl. VII, fig. 1 (1862).

Gyna vetula, Brunner von Wattenwyl, Nouv. Syst. Blatt., p. 267 (1865).

Distinguished by the piceous antennae, the tegmina mottled with testaceous and the contiguous eyes in the male.

German East Africa (Vienna Mus., type of vetula; Berlin Mus.; Stockholm Mus.); Mozambique (Berlin Mus., type of maculipennis); RHODEsia (Oxford Mus.).

15. G. kazungulana, Gig.-Tos.

Gyna kazungulana, Giglio-Tos, Boll. Mus. Torino xxii, No. 563, p. 3 (1907).

This is little more than a local race of the preceding species, it is smaller in size but otherwise scarcely differs. The type specimen has the pronotum heavily suffused with castaneous, but this is not the case in an example 
from Kilimandjaro which I am unable otherwise to distinguish from the type.

UPPer Zambesi, Kazungulu (Turin Mus., type); Kilimandjaro (Buda-Pesth Mus.).

\section{G. lurida, Sauss.}

Gyna lurida, Saussure, Abh. Senckenb. Ges., xxi, p. 581 (1899).

The female is to be distinguished from that of maculipennis by the different form of the supra-anal lamina.

Zanzibar (Senckenberg Mus., types; Vienna Mus.).

The last three species are so closely allied, that the following tabulation of the differences between the males will help towards their identification.

\begin{tabular}{|c|c|c|c|}
\hline & maculipennis. & kazungulana. & lurida. \\
\hline $\begin{array}{l}\text { Length of } \\
\text { body }\end{array}$ & $19 \mathrm{~mm}$. & $15 \cdot 2 \mathrm{~mm}$. & $15 \mathrm{~mm}$. \\
\hline $\begin{array}{l}\text { Distance } \\
\text { apart of } \\
\text { eyes }\end{array}$ & $\begin{array}{l}\text { Equals thickness } \\
\text { of first antennal } \\
\text { joint }\end{array}$ & $\begin{array}{l}\text { Equals thickness } \\
\text { of first antennal } \\
\text { joint }\end{array}$ & Almost touching \\
\hline $\begin{array}{l}\text { Colour of } \\
\text { head }\end{array}$ & Rufo-castaneous & Rufo-castaneous & Piceous \\
\hline $\begin{array}{l}\text { Colour of } \\
\text { antennae }\end{array}$ & $\begin{array}{l}\text { First two joints } \\
\text { castaneous, re- } \\
\text { mainder piceous }\end{array}$ & $\begin{array}{l}\text { First two joints } \\
\text { castaneous, re- } \\
\text { mainder piceous }\end{array}$ & Piceous to base \\
\hline $\begin{array}{l}\text { Frons } \\
\text { above } \\
\text { clypeus }\end{array}$ & Smooth & Striate & Strongly striate \\
\hline $\begin{array}{l}\text { Supra-anal } \\
\text { lamina }\end{array}$ & $\begin{array}{l}\text { Sub-quadrate, apex } \\
\text { faintly emargin- } \\
\text { ate }\end{array}$ & $\begin{array}{l}\text { Sub-quadrate, apex } \\
\text { distinctly emar- } \\
\text { ginate }\end{array}$ & $\begin{array}{l}\text { Trigonal, apex } \\
\text { faintly emargin- } \\
\text { ate }\end{array}$ \\
\hline
\end{tabular}

\section{G. incommoda, sp. n.}

đ. Pale flavo-testaceous. Antennae fuscous, castaneous at base. Eyes nearly touching on vertex. Frons and face rufous. Posterior part of pronotum hyaline, lyrate markings rufo-castaneous. Tegmina moderately broad, outer margin sinuate, uniform flavo-testaceous becoming hyaline towards apex. Wings with anterior part suffused with flavid, ulnar vein with 14 rami, 9 being incomplete.

TRANS. ENT. SOC. LOND. 1909.-PART II. (MAY) Y 
Margins of pronotum beneath and mediastinal area of tegmina beneath bright rufo-castaneous. Abdomen and legs rufo-testaceous. Supra-anal lamina sub-quadrate, apex slightly emarginate, barely exceeded by the sub-genital lamina which is asymmetrical and furnished with two styles.

o. Similar but rather darker in colour, distance of eyes apart rather greater than length of 1st antennal joint. Antennae piceous, castaneous at base. Posterior part of pronotum concolorous with anterior part. Tegmina broader, their outer margin very sinuate. Wings with anterior part suffused with rufo-castaneous.

\$. Total length $22 \mathrm{~mm}$; length of body $16 \mathrm{~mm}$.; length of tegmina $20 \mathrm{~mm}$. ; pronotum $6.8 \mathrm{~mm} . \times 8 \mathrm{~mm}$.

q. Total length $28 \mathrm{~mm}$. ; length of body $21 \mathrm{~mm}$.; length of tegmina $25 \mathrm{~mm}$.; pronotum $8.5 \mathrm{~mm} . \times 10.9 \mathrm{~mm}$.

Somaliland, Brava (Genoa Mus., types $\hat{\delta}$ and $q$ ); German E. Africa, Lake Jipe, Katona (Budapest Mus.).

The species is perhaps most nearly related to G. laticosta, Walk., but is distinguished by the well-defined lyrate markings on the pronotum. The specimen from Katona is rather larger than the type $q$, but otherwise is identical.

18. G. fervida, Sauss.

Panchlora fervida, Saussure, Rev. Zool. (2) xvi, p. 341 (1864).

Panchlora lata, Walker, Cat. Blatt. Brit. Mus., p. 31 (1868).

Panchlora spurcata, Walker, op. cit., p. 34 (1868).

? Trichomera insignata, Kirby, Ann. Mag. Nat. Hist., ser. 6 , xviii, p. 257, Pl. XII, f. 5 (1896).

\$. Testaceous. Distance apart of eyes on vertex of head equal to length of 1st antennal joint; frons with castaneous macula ; neither vertex nor frons striate. Antennae rufo-fuscous, basal third rufotestaceous. Pronotum with clearly defined lyrate marking. Tegmina rather broad, mottled with testaceous, a macula on disc and a curved fascia at apex, rufescent; the piceous spot between radial and mediastinal veins obsolescent or absent. Wings hyaline, the marginal field flavo-testaceous, ulnar vein with 10 rami, 7 being incomplete. Abdomen and legs rufo-testaceous; supra-anal lamina subquadrate, apex not emarginate, barely surpassing the sub-genital plate which is small and slightly asymmetrical. Tarsi rather short.

q. Similar, but eyes a little farther apart; tegmina broader; 
anterior part of wings suffused with castaneous, ulnar vein with 11 rami ; supra-anal lamina sub-bilobate; sub-genital lamina semiorbicular, ample.

t. Total length $20 \mathrm{~mm}$. ; length of body $17 \mathrm{~mm}$.; length of tegmina $16 \mathrm{~mm}$.; pronotum $6 \mathrm{~mm} . \times 8 \mathrm{~mm}$.

q. Total length $27 \mathrm{~mm}$. ; length of body $24 \mathrm{~mm}$.; length of tegmina $22 \mathrm{~mm}$; pronotum $8.5 \mathrm{~mm} . \times 10 \mathrm{~mm}$.

Senegambia (Paris Mus., type of fervida); Gambia (British Mus., type of lata); Togo (Berlin Mus.); Benin (Oxford Mus.); Gaboon (British Mus., type of spurcata); Congo Free State (Brussels Mus.).

\section{G. aestuans, Sauss.}

Panchlora aestuans, Saussure, Mém. Soc. Sci. Phys. Nat. Genève, xvii, p. 159, Pl. I, f. 20 (1864).

đ. Differs from fervida by the smaller distance apart of the eyes, the strongly striate vertex, the more heavily marked frons, the piceous antennae, the concolorous tegmina without macula or fascia, the supra-anal lamina with slightly emarginate apex.

Length of body $17.3 \mathrm{~mm}$. ; length of tegmina $20 \mathrm{~mm}$.; pronotum $7 \mathrm{~mm} . \times 9 \mathrm{~mm}$.

Senegal (Geneva Mus., type).

20. G. caffrorum, Stål.

Panchlora caffrorum, Stål, Oefv. Vet.-Akad. Förb. xiii, p. 167 (1856).

Epilampra conspicua, Walker, Cat. Blatt. Brit. Mus., p. 67 (1868).

Panchlora scripta, Walker, op. cit., p. 183 (1868).

Gyna fervida, Bormans, Ann. Soc. ent. Belg., xxv, p. 21, Pl. I, f. B. (1881).

Gyna 'stridulans, Karny, Denkschr. med.-nat. Ges. Jena, xiii, p. 382, Pl. XXI, f. 28, Pl. XXII, ff. 29-32 (1908).

To be distinguished from $G$. maculipennis by the eyes being nearly $1 \mathrm{~mm}$. apart in the $\hat{\delta}$; the vertex is striate and the pronotum is usually heavily marked. Dr. Karny has kindly compared a specimen of caffrorum with his species and informs me that they are practically identical.

Natal (Stockholm Mus., type of caffrorum); "South 
Africa" (British Mus., type of scripta ; Oxford Mus., Borman's example); Lake N'GaMi (Castelnau), (British Mus., type of conspicua ; Oxford Mus.); S.W. Africa, Amboland (G. Schinz), (Senckenberg Mus.); German S.W. Africa, Otjosondu (Berlin Mus., type of stridulans).

21. G. aurivillii, Borg.

Gyna aurivillii, Borg, Bih. Svensk. Vet.-Akad. Handl., xxviii, Afd. 4, No. 10, p.20, Pl. II, f. 5 (1902).

This is very close to the preceding species, but the eyes in the of are closer together and in both sexes the tegmina have no rufescent macula on the disc of the tegmina, there is however a conspicuous piceous spot between the radial and mediastinal veins which is reduced or absent in caffrorum. The fusing of the lyrate markings on the vertex is a variable character.

\$. Total length $27 \mathrm{~mm}$. ; length of body $23 \mathrm{~mm}$.; length of tegmina $24 \mathrm{~mm}$. ; pronotum $8.4 \mathrm{~mm} . \times 9 \cdot 4 \mathrm{~mm}$.

Kamerun (Stockholm Mus., type; Berlin Mus.).

\section{G. hyalina, sp. n.}

. Clear testaceo-hyaline, head and antennae, abdomen and legs rufo-castaneous. Eyes close together on vertex (less than $1 \mathrm{~mm}$. apart). Pronotum anteriorly and posteriorly faintly striate, lyrate markings on disc castaneous and fused together. Tegmina moderately broad, immaculate, mediastinal field at base, mediastinal and anal veins castaneous. Wings with costal margin suffused with flavid, ulnar vein with $17 \mathrm{rami}, 11$ being incomplete. Supra-anal lamina deeply bilobate, sub-genital lamina of the usual form. Formula of apical spines of the femora, $\frac{0}{1}, \frac{1}{1}, \frac{1}{1}$; no genicular spine on front femora.

Total length $24 \mathrm{~mm}$; length of body $17.8 \mathrm{~mm} . ;$ length of tegmina $20 \mathrm{~mm}$. ; pronotum $6.9 \mathrm{~mm} . \times 8 \mathrm{~mm}$.

Congo Free State, Iringui (Musée du Congo); Victoria Nyanza, Bugala, Sesse Archipelayo (E. Bayon), (Genoa Mus.).

Readily distinguished by the peculiar hyaline appearance of the pronotum and tegmina; also by the approximation of the eyes, an unusual feature in the females of this genus. 
23. G. colini, Rochebr.

Gyna colini, Rochebrune, Bull. soc. philomath., ser. 7, vii, p. 176 (1883).

The description is useless for purposes of identification, and I cannot obtain the type.

\section{Senegambia.}

\section{Genus Pseudogyna, nov.}

Allied to Gyna, Br., but differs as follows :-pronotum posteriorly less strongly produced; tegmina and wings not exceeding apex of abdomen; cerci very short and obscurely articulated; posterior metatarsus very long, considerably exceeding the succeeding joints, biseriately spined beneath.

The genus is intermediate between Gyna and Phenacisma.

\section{P. intermedia, sp. n.}

q. Head piceous, genae and mouth-parts testaceous. Eyes rather wide apart. Pronotum testaceous with a discoidal piceous lyrate marking, posteriorly produced but much less so than in Gyna and Phenacisma. Tegmina not quite extending to apex of abdomen, castaneous, mediastinal field testaceous, venation well marked, mediastinal vein piceous. Wings of equal length with tegmina, anterior part semi-coriaceous, posterior part slightly reduced, ulnar vein ramose. Abdomen mottled with testaceous and piceous ; supraanal lamina quadrate, apex emarginate; sub-genital lamina semiorbicular, ample. Legs castaneous.

Length $25 \mathrm{~mm}$.; length of tegmina $19.5 \mathrm{~mm}$.; pronotum $7 \cdot 1 \mathrm{~mm}$. $\times 10 \mathrm{~mm}$.

N.E. Rhodesia, Hills near Fort Jameson, 4,000-5,000 ft. (S. A. Neave), (Oxford Mus.).

In colouring the species is very like the next.

\section{Genus Phenacisma, Karsch.}

Phenacisma semialata, sp. n. (Pl. IX, fig. 38.)

o Allied to $P$. peltata, Karsch, but smaller and less convex, tegmina coriaceous not semi-corneous, more rounded at apex, anal vein well marked, wings larger. Head piceous, a band between the 
eyes and the mouth-parts rufo-testaceous. Eyes rather wide apart. Antennae piceous. Pronotum as in peltata, but discoidal lyrate marking larger. Tegmina suffused with castaneous, not extending beyond apex of abdomen. Wings much reduced, coriaceous, veins thickened, ulnar vein with 12 rami, vena dividens giving off transverse venules, posterior part of wing not folding in fan-like manner. Abdomen testaceous, mottled with fuscous, supra-anal lamina quadrate, apex slightly emarginate. Cerci very short, sub-genital lamina semiorbicular, ample. Coxae testaceous, legs castaneous, posteriort arsi as in $P$. peltata.

Length $23 \mathrm{~mm}$.; length of tegmina $19 \mathrm{~mm}$; length of wings $10 \mathrm{~mm}$; pronotum $8 \mathrm{~mm} . \times 11 \cdot 2 \mathrm{~mm}$.

N.E. Rhodesia, E. Loangwa district, Petauke 2,400 ft. (S. A. Neave), (Oxford Mus.).

In $P$. peltata, Karsch, the wings are reduced to minute corneous scales from which the venation has disappeared, these scales represent only the anterior parts of the wings; semialata in its wing-structure is a connecting link between Pseudogyna and peltata.

The genus Gynopeltis, Gerst. (sub.-fam. Perisphaeriinae) in the male sex is very like Gyna, Br., but may be distinguished by the shortly produced, trigonal supra-anal lamina, exceeded by the sub-genital lamina and by a hooked lappet, which is the left posterior angle of the 8th abdominal sternite, projecting from beneath the 7 th abdominal sternite on the left side; there is only one style and this is minute. In G. cryptospilo, Wlk. [= picta, Gerst.] the front femora have four or five spines on the anterior margin beneath. The females of the genus are entirely apterous.

The following species appears to be new :-

\section{Gynopeltis neavei, sp. n. (Pl. IX, fig. 39.)}

f Testaceous; head with vertex and an irregular band between the ocelli castaneous. Eyes $75 \mathrm{~mm}$. apart; antennae piceous. Pronotum with a lyrate piceous marking on the disc as in the genus Gyna. Tegmina testaceous, rather narrow, outer margin sinuate, a line at base of mediastinal vein and the anal vein piceous, disc indistinctly suffused with castaneous, the part of the right tegmen overlapped by the left, castaneous. Wings with anterior part suffused with flavid, ulnar vein with 12 rami, 7 being incomplete. Abdomen above rufo-testaceous, beneath testaceous. Cerci rather 
Mr. R. Shelford's Studies of the Blattidae. $\quad 327$ stout, incurved. Legs testaceous, piceous above, front femora unarmed on anterior margin beneath.

Total length $27 \mathrm{~mm}$. ; length of body $22 \mathrm{~mm}$. ; length of tegmina $24 \mathrm{~mm}$; pronotum $6 \cdot 2 \mathrm{~mm} . \times 8 \mathrm{~mm}$.

N.E. Rhonesia, East Loangwa district, Petauke $2,400 \mathrm{ft}$. (S. A. Neave), (Oxford Mus.).

\section{Explanation of Plates VII-IX.}

[See Explanation facing the PLATEs.

June 4, 1909. 


\section{$2 \mathrm{BHL}$ Biodiversity Heritage Library}

Shelford, Robert W. C. 1909. "IV. Studies of the Blattidae." Transactions of the Entomological Society of London 57, 253-327. https://doi.org/10.1111/j.1365-2311.1909.tb02172.x.

View This Item Online: https://www.biodiversitylibrary.org/item/51003

DOI: https://doi.org/10.1111/j.1365-2311.1909.tb02172.x

Permalink: https://www.biodiversitylibrary.org/partpdf/37251

\section{Holding Institution}

Smithsonian Libraries

\section{Sponsored by}

Smithsonian

\section{Copyright \& Reuse}

Copyright Status: Public domain. The BHL considers that this work is no longer under copyright protection.

This document was created from content at the Biodiversity Heritage Library, the world's largest open access digital library for biodiversity literature and archives. Visit BHL at https://www.biodiversitylibrary.org. 